\title{
Petitioning the King
}

The preceding chapter examined the king's confirmation of urban charters during the extramural greeting. Municipal councils did not attempt to win further rights at this stage of the ceremony; indeed, they insisted that the king did not alter the scope of their liberties during the extramural oath taking. For instance, the text of the oath the king took at La Rochelle stated that he was to confirm the city's rights as they stood, without making any amendments. ${ }^{1}$ The townspeople's insistence on the immutability of the oath was probably to allay any fears that the monarch would use the act to diminish or abrogate municipal liberties. Hence, the extramural swearing of liberties was a straightforward confirmation of urban rights. Despite the fact that the oath-taking element of the ceremony was eroded over time, a royal entry continued to provide town councils with an opportunity to petition the monarch for new liberties right through to the late sixteenth century. This was particularly important for civic leaders, as they could otherwise find it difficult to gain access to the king and his ministers.

Historians have typically followed Gaston Zeller's assertion that it was easy to gain access to the French monarch before the reign of Henry III. ${ }^{2}$ Most recently, Robert Knecht has asserted that 'the king of France in the early sixteenth century had been easily accessible... Access to the court was easy: anyone decently dressed was admitted. ${ }^{3}$ This chapter argues that such claims about the accessibility of the French court have been overstated. It was one thing to gain access to the king's court and quite another to secure contact with the monarch and those in power. Certainly, the perception of accessibility (if not the reality) was a central feature of French kingship from the reign

1 Rivaud, Entrées princières, 119.

2 Gaston Zeller, Les institutions de la France au XVIe siècle (Paris, 1948), 97-99. For the continuing influence of Zeller's view, see: Ronald G. Asch, 'The Princely Court and Political Space in Early Modern Europe', in Beat Kümin, ed., Political Space in Pre-industrial Europe (Farnham, 2009), 45; Monique Chatenet, La cour de France au XVI ${ }^{e}$ siècle: vie sociale et architecture (Paris, 2002), 135-40; idem, 'Henri III et l'ordre de la cour. Evolution de l'étiquette à travers les règlements généraux de 1578 et de 1585', in Jacqueline Boucer and Robert Sauzet, eds., Henri III et son temps (Paris, 1992), 133-39; idem, 'Etiquette and Architecture at the Court of the Last Valois', in Mulryne and Goldring, Court Festivals of the European Renaissance, 89-94; J.-F. Solnon, La cour de France (Paris, 1987), 31-32, 41-42.

3 Knecht, Henry III, 67-70. 
of Louis IX, whose reign was looked upon as a golden era precisely because the saintly king had removed many of the obstacles that separated the monarch from his subjects. French kings were adept at maintaining the appearance of accessibility, while at the same time blocking their subjects' attempts to gain access to them. Historians' assertions about the openness of the French court are largely based on either the idealised projection of Valois kingship found in royal documents or on the evidence gleaned from ambassadors' letters. In contrast to the accessibility of the French monarch found in these sources, municipal documents make it clear that towns encountered great difficulties when they tried to gain contact with the king and his ministers. ${ }^{4}$ Furthermore, the process of obtaining access to the royal council was governed by protocol and concerns with precedence, which made the task painfully slow and laborious. As Timothy Watson has noted, even the representatives of the most important cities of the kingdom 'had no option but to wait around, often for weeks, outside the council chamber, hoping for an invitation to present their case. ${ }^{5}$ Municipal councils could not be sure that their delegations would be granted an opportunity to present their requests to the royal council. On the other hand, royal entries provided civic governments will immediate access to the king and his ministers, thus speeding up the workings of government.

Royal entries benefitted civic elites in a number of important ways relating to the winning of grants. First, they enabled urban governments to speak to the king in person about pressing matters, such as economic hardships, problems with garrisons and other military obligations, as well as natural catastrophes and crop failures. Second, they allowed towns to avoid the expense of having to send a delegation to court. ${ }^{6}$ In addition to the financial cost of keeping a delegation at court (lodgings, victuals, transport, etc.), urban delegations also had to pay the royal officials who controlled access to the conseil privé if they hoped to have an opportunity to present their requests to the king's ministers. Third, and most important, custom bound the king to grant the petitions offered to him at a royal entry. We can see all these benefits in action when we examine Avignon's efforts to win new grants from the Crown in the mid-155os. Avignon's consuls sent one M. de Panisse to Henry II's court at Blois in 1556 to gain access to the conseil privé and petition its members for new economic

4 O. Mattéoni, 'Plaise au roi: les requêtes des officiers en France à la fin du Moyen Age', in H. Millet, ed., Suppliques et requêtes: le gouvernement par la grâce en Occident (XII ${ }^{e}-X V^{e}$ siècle) (Rome, 2003), 268-307. For urban delegations see: Rivaud, Villes et le roi, 195-97.

5 Watson, 'Friends at Court', 288-89.

6 Gisela Naegle, 'Vérités contradictoires et réalités constitutionnelles. La ville et le roi en France à la fin du Moyen Âge', Revue historique 632 (2004), 727-28. 
rights for the city. Although Panisse managed to obtain an audience with the conseil privé, he was unable to win any new grants. Not only did Panisse's mission end in failure, it also drained municipal finances. Panisse wrote to the consuls on 24 February to inform them of his desperate situation, stating he was returning to Avignon because of the high financial costs of remaining at court. ${ }^{7}$ Five days after Panisse sent his despondent letter of 24 February 1556 , he wrote again to the consuls to say that Charles of Lorraine (one of the most powerful men in the kingdom) had advised him of Henry II's intention to make a ceremonial entry into Avignon. Specifically, Charles told Panisse that the city's petitions for new grants were 'propitious to put before the king when he makes his entry into your town'. ${ }^{8}$ As the cardinal of Lorraine made clear to Avignon's delegate, a royal entry provided one of the very best opportunities for municipal councils to obtain new liberties from the monarch. To take a further example, when Francis I cancelled his planned entry into Toulouse in March 1526 , the council sent a delegation to find the king and obtain his confirmation of its existing liberties. Crucially, the delegates were instructed not to petition the king for new liberties. ${ }^{9}$ The consuls likely wanted to wait until Francis entered the city to obtain these liberties, as an entry provided the most favourable time for the negotiation of new privileges.

Municipal councils often found it tough to gain access to the king and his council. For example, a delegation from Lyon waited outside the conseil privé every day for two months in 1560 without obtaining a hearing for their petition for tax exemption. ${ }^{10}$ Difficulties in gaining access to the monarch and his ministers were not just a feature of a sedentary court fixed around a royal palace. Towns also found it difficult to gain access to the king while he was on progress, when - in theory at least - the ruler was meant to be more accessible, like Saint Louis, as he travelled around his kingdom to meet his subjects. The only time an urban government could guarantee that they would have access to the monarch was when he made an entry into their town. When the king was outwith their walls, civic leaders found it hard to secure direct contact with him. When Dijon's rulers learnt that Francis I was travelling through Burgundy in 1536, they sent a deputation to the nearby castle of Pagny to seek an audience with the king and request an octroi of 5,000 livres to cover the damage imperial

\footnotetext{
7 AD Vaucluse, AM Avignon AA 42, n. 9.

8 AD Vaucluse, AM Avignon AA 42, n. 10.

9 AM Toulouse BB 9, fols. 3or-34v.

10 Watson, 'Friends at Court', 288-89.
} 
troops had caused to the city's faubourgs. ${ }^{11}$ However, despite their best efforts, Dijon's municipal delegation could not gain access to the king. As such, the échevins had to settle with presenting their petition to the général des finances, Guillaume Prudhomme, who passed it to his son-in-law, François de Pré, lord of Cossigny-en-Brie and a member of the king's council. ${ }^{12}$ Pré promised to implement any requests the king authorised for the city, although he advised the échevins that their petition was unlikely to reach the monarch. In an effort to gain access to the king, the civic council asked the admiral of France, Philippe de Chabot-Brion (who was one of Francis I's favourites ${ }^{13}$ ) to persuade the monarch to visit Dijon, thus allowing the councillors to hand their petitions directly to the king. ${ }^{14}$ Although municipal councils had to build networks of reciprocity with members of the royal entourage, these efforts were worthwhile because a ceremonial entry guaranteed them access to the king. Even the rulers of towns lying outside France tried to persuade the Valois monarch to make an entry so that they could offer him their petitions. When the consuls of Marseille (which was not then under French rule) learned in December 1355 that John II was to visit the region, they prepared a ceremonial entry specifically so that they could present a number of requests to him. As well as asking the Valois king to order his subjects to stop harassing Marseille's merchants, the consuls also petitioned him to release the townspeople who were then imprisoned in Montpellier as a consequence of letters of marque he had issued against the city. ${ }^{15}$

11 For the granting of octrois, see: David Potter, War and Government in the French Provinces: Picardy, 1470-1560 (Cambridge, 1993), 233-64; David Rivaud, Les villes au Moyen Âge dans l'espace français XII ${ }^{e}-X V I^{e}$ siècle (Paris, 2012), 30-31; Bernard Chevalier, "The Policy of Louis XI towards the Bonnes Villes: The Case of Tours', in P. S. Lewis, ed., The Recovery of France in the Fifteenth Century (London, 1971), 271-72.

12 For Prudhomme, see: Rémy Scheurer, ed., Correspondence du Cardinal Jean du Bellay, 2 vols (Paris, 1969), i. 123; Camille Trani, 'Les magistrats du grand conseil au XVIe siècle (1547-1610)', Mémoires publiés par la fédération des sociétés archéologiques de Paris et de l'̂lle-de-France 42 (1991), 139. The généraux des finances were responsible for taxation: J. A. Guy, 'The French King's Council, 1483-1526', in R. A. Griffiths and J. Sherborne, eds., Kings and Nobles in the Later Middle Ages (London, 1986), 285.

13 Cedric Michon, 'Conseils et conseillers sous Francois I ${ }^{\mathrm{er}}$ ', in Cedric Michon, Les conseillers de Francois I ${ }^{\text {er }}$ (Rennes, 2011), 41.

14 Gouvenain, Inventaire sommaire, Dijon, i. 60

15 Ам Marseille в в 21, fols. 88r-9or, 95r-97r, 103r-107r, 108r. For requests presented by the consuls of Marseille at ceremonial entries, see: Noël Coulet, 'Les entrées solennelles en Provence au XIV siècle', Ethnologie française 1 (1977), 64. For Marseille and letters of 
Urban elites commonly used the promise of a magnificent entry to entice the king to visit their town, so that they could offer him their requests. When Francis I passed close to Gap on his way to campaign in Milan in 1515, the municipal council sent a speaker (Claude Olier) to greet the monarch and persuade him to ceremonially enter the town. While Francis was unable to enter the city at this time, he promised to visit Gap on his return from Italy, hence sustaining the French monarchy's impression that it was open to receive the pleas of its subjects. ${ }^{16}$ In October 1542, Agen prepared an entry for Francis I. As the king was unable to visit the town, his sent a deputation in his place to meet with the consuls and thus show his willingness to listen to urban requests. ${ }^{17}$ Furthermore, urban governments hoped that the staging of a magnificent entry would encourage the monarch to make an extended stay, providing them with further opportunities to gain access to the king and those who travelled with him. According to Montpellier's municipal records, Francis I was so enamoured with the entry he received from the city in 1533 that he remained in the city for nine days, which was longer than the duration of the other urban visits he made during this progress through Languedoc. ${ }^{18}$ As towns and cities were in constant competition with their neighbours, Francis's protracted stay at Montpellier allowed its consuls to secure increased contact with the king as well as hampering the efforts of other urban administrations to access the monarch. French towns used the time they had the king within their walls (whether it be for nine days or just a single afternoon) to win his favour and persuade him to grant them new rights. They deployed a number of strategies to gain contact with the monarch, the most important of which was gift giving.

\section{Gift-Giving}

The post-entry ceremonies and festivities provided the best time for urban rulers to interact directly with the monarch. For instance, the organisation of a banquet gave municipal councils the means to access the king as well

marque in the fourteenth century, see: Christopher D. Beck, 'Seizing liberties: private rights, public good, and letters of marque in medieval Marseille' (PhD thesis, Fordham University, 2012).

16 Théodore Gauiter, Précis de l'histoire de la ville de Gap (Gap, 1944), 65.

17 Auguste, Inventaire sommaire, Agen, 23

18 Alicot, Petit Thalamus de Montpellier, 509. 
as creating a sense of conviviality through the provision of food, drink and entertainment. ${ }^{19}$

Banquets allowed civic councillors to secure contact with the people at the very centre of power, including leading nobles and royal officials. More importantly, town governments used banquets to petition the king for new liberties. After entering Nîmes on 23 December 1362, John II invited the consuls to dine with him and present their requests. ${ }^{20}$ The king made an abundance of grants during this progress, which came soon after his return from England. Whereas Paris and many other northern urban communities had challenged his son's government during his captivity, southern towns had both remained loyal and sent John gifts of goods and money. ${ }^{21}$ In return for their generosity, the towns of Languedoc obtained extensive new liberties at the banquets which followed John's entries. ${ }^{22}$

The showcasing of regional and national delicacies provided civic councillors with an opportunity to promote the extent of their trading networks, which they sought to maintain by obtaining grants from the king at an entry. When Francis I entered Angers in June 1518, the municipal council prepared a banquet that included delicacies from across northern France: loches from

19 Serge ter Braake, 'Brokers in the Cities: The Connections between Princely Officers and Town Officials in Holland at the End of the Middle Ages (1480-1558)', in Sheila Sweetinburgh, ed., Negotiating the Political in European Urban Society, c.140o-c.16oo (Turnhout, 2013), 170. See also: Dolan, 'Rites d'accueil', 291-93; Jean-Pierre Leguay, La ville de Rennes au XVe siècle à travers les comptes des Miseurs (Rennes, 1968), 309-15; idem, 'Banquets, cadeaux alimentaires et autres présents aux visiteurs de marque dans les villes françaises à la fin du moyen âge', in Jeux, sports et divertissements au moyen âge et à l'âge classique (Paris, 1993), 193-213; idem, 'Un aspect de la sociabilité urbaine: cadeaux et banquets dans les réceptions municipales de la Bretagne ducale au XVe siècle', in Charpiana: Mélanges offerts par ses amis à Jacques Charpy (Rennes, 1991), 349-6o; C. M. Woolgar, 'Gifts of food in medieval England', Journal of Medieval History 37 (2011), 6-18. Kings could also invite urban administrations to attend banquets organised by royal officials: La Grange, 'Entrées des souverains', 28; Guenée and Lehoux, Entrées royales françaises, 100, 126; Bonnardot, Registres Paris, 1499-1526, 221; Guérin, Registres Paris, 1539-1552, 183.

Louis J. Thomas, 'Séjour du roi Jean II le Bon à Villeneuve-lès-Avignon (16 novembre 1362-10 mai 1363)', Cahiers d'histoire et d'archéologie. Revue méridionale d'histoire locale, de géographie humaine, d'archéologie 6 (1933), 401.

21 Claude de Vic and J.Vaissette, Histoire générale de Languedoc: avec des notes et les piècesjustificatives, 16 vols (Toulouse, 1872-93), ix. 688; x. 1153; Charles-Victor Langlois, Instructions remises aux députés de la commune de Montpellier qui furent envoyés au roi Jean pendant sa captivité en Angleterre (1358-1359) (Montpellier, 1888), 2-7; Laurière, Ordonnances rois de France, iii. 88, 106. 
Bar-sur-Seine (Champagne); eels from Maine; barbells from Saint-Florentin (Champagne); pike from Chalôns-en-Champagne; trout from Les Andelys; tarts from Chartres, and purées from Arras. ${ }^{23}$ The range of goods offered to Francis encapsulated the scope of the Angers' trading networks, which extended across the urban belt of northern France. In order to provide these gifts to Francis (which symbolised the town's wealth and thus its value to the Crown), the échevins required Francis to use his powers to support their commercial interests. Municipal councils drew on their connections with members of the king's household to tailor the post-entry banquet to suit the monarch's tastes and thus further endear the town to him. For example, in advance of Charles VIII's entry into Reims 1484, the royal maitre d'hôtel informed the échevins of the king's favourite dishes. ${ }^{24}$ In addition to food, towns offered a range of other presents to the king during the banquets that were related to feasting, including alcohol and tableware. The presentation of these gifts provided a good opportunity for urban rulers to win new rights and liberties because the monarch was expected to offer a counter-gift of greater value than that provided by the town in order to affirm his superior status. ${ }^{25}$

From the fourteenth century, it was customary for visiting dignitaries to be introduced to the French king as soon as he had finished dining. ${ }^{26}$ In an awareness of court protocol, urban delegations gave their requests to king at the conclusion of the meal. After presenting Charles viII with gifts during his post-entry banquet at Abbeville 1493, the town's leaders petitioned him for exemption from the taille. ${ }^{27}$ Likewise, when Eleanor of Austria entered Paris in 1531, the municipal council sent a delegation to invite her to dine in the town hall so that they could present her with a silver chandelier. They wanted to use the banquet to encourage her to promote the interests of the city with

23 Aimé de Soland, 'Réceptions et galas en Anjou', Bulletin historique et monumental de l'Anjou 4 (1868), 334-35.

24 Édouard Bartholomé, 'Mémoires de Jean Foulquart. Procureur de l'échevinage à Reims 1479-1499', Revue de Champagne et de Brie 2 (1877), 48.

25 Laure Verdon, 'Don, échange, réciprocité. Des usages d'un paradigm juridique et anthropologique pour comprendre le lien social médiéval', in Lucien Faggion and Laure Verdon, eds., Le don et le contre-don. Usages et ambiguités d'un paradigm anthropologique aux époques médiévale et moderne (Aix-en-Provence, 2010), 9-22; Claude Gauvard, 'Ordonnance de réforme et pouvoir legislative en France au XIVe siècle', in André Gouron and Albert Rigaudière, eds., Renaissance du pouvoir législatif et genèse de l'Etat (Montpellier, 1988), 97.

26 Chatenet, Cour de France, 120.

27 Ledieu, 'Charles VIII à Abbeville', 57. 
her husband the king and his councillors. ${ }^{28}$ Italian civic elites also exploited their knowledge of French ceremonial practices to obtain substantial political concessions from Valois monarchs at their entries. When Charles viII made his entry into Pisa on 9 November 1494, a delegation formed of the leading citizens came to the king during his banquet at the Opera del Duomo to petition him for 'libertà', by which they meant freedom from Florentine dominance. For Charles, this was a straightforward grant of a petition for new rights, which he could expect to receive when entering any French town. The French king did not appreciate the full ramifications of this grant, which was celebrated throughout the streets of Pisa with festivities and the tearing down of symbols of Florentine dominance. In the days following Charles viII's grant, Florentine officials were expelled from the city and a republican government installed. ${ }^{29}$ As we see, urban governments could win substantial rights by offering gifts during the conviviality created by a feast. Yet, should a king decide to remain in the town for one night or more there were other opportunities for urban governments to give him their requests.

Rather than offer gifts and petitions to the king at the conclusion of the banquet, municipal administrations could seek to gain entry to the king's private quarters; indeed, there are a number of reasons why it was more desirable to do so. First, it meant they could time their visits to coincide with the daily meeting of the royal council, which took place in the king's private chambers immediately after he had dined. While Paris was the administrative centre of the kingdom, the royal council accompanied the monarch on progress. The council was at the centre of government and it took the major decisions affecting the kingdom's administration. ${ }^{30}$ By timing their gift presentation to occur during a sitting of the royal council, municipal councils had access to the most powerful people in France. ${ }^{31}$ Second, the less-public setting of the king's rooms

28 Godefroy, Cérémonial françois, i. 802.

29 When Charles entered the city again in June 1495, a triumphal arch with the depiction of Charles's horse trampling on a Florentine lion was amongst the decorations: Mitchell, Majesty of State, 61-2; Gene Brucker, Florence: The Golden Age, 1138-1737 (Berkeley, 1998), 180.

30 Emmanuel Le Roy Ladurie, The French Royal State, 1460-1610, trans. Juliet Vale (Oxford, 1994), 47; M. G. A. Vale, The Princely Court: Medieval Courts and Culture in North-West Europe, $1270-1380$ (Oxford, 2001), 138.

31 For the composition and evolution of the king's council see: Jean Barbey, Être roi: le roi et son gouvernement en France de Clovis à Louis XIV (Paris, 1992), 329-42; Mikhail Harsgor, Recherches sur le personnel du Conseil du roi sous Charles VIII et Louis XII, 2 vols (Lille, 1980), i. 188-204, 256-461; Guy, 'French King's Council', 274-94; R. J. Knecht, Renaissance Warrior and Patron: The Reign of Francis I (Cambridge, 1994), 50-53; Michon, 'Conseils 
facilitated the creation of links between the urban elite and the monarch. The opportunity to acquire close contact with the king following the entry became more important for townspeople as a result of the changes made to the extramural greeting during the mid-sixteenth century (see chapter one). The degree to which the monarch was in the public gaze profoundly affected the nature of his contact with the municipal elite. There was an acute shift in the king's behaviour between the extramural greeting (which took place in the open air and before an audience of hundreds - and sometimes thousands - of people) and the less public setting of the gift-giving ceremony. As we saw in the previous chapter, Henry II sat in silence as he received the prévôt-des-marchands' greeting at Paris in 1549 and had the chancellor reply on his behalf. Yet when the members of the municipal council met Henry in his private chambers after the public entry, the king received their gifts and thanked the councillors directly before listening to their requests. ${ }^{32}$ Likewise, during the gift presentation that took place in Henry II's lodgings following his entry into Rouen in 1550, the king thanked the échevins for the present and received their requests. ${ }^{33}$ Henry's concern to appear aloof from his urban subjects diminished as soon as he was out of the wider public's gaze. By controlling the environment, municipal elites could exploit their exclusive contact with the king in order to win new rights.

The ease with which municipal councils were able to gain access to the king depended on the status of his residence. In part, the location of the king's lodgings reflected the nature of his authority in the region. For example, kings of France entering Angers before the late fifteenth century lodged in the abbey of Saint-Aubin; however, once Louis XI united Anjou with the royal domain in 1480 , visiting monarchs stayed in the castle. ${ }^{34}$ Valois kings tended to stay in royal palaces situated in or close to urban centres, as at Compiègne, Paris, Senlis and Tours. There was also a geographical element to the choice of royal residence, as the majority of royal palaces were located in the north of the kingdom, especially around the Loire valley and the Île-de-France. ${ }^{35}$ Because urban governments had no control over royal palaces, they paid royal staff to gain entry to these buildings during a royal visit. When Charles viII entered

et conseillers', 11-81; Roland Mousnier, Le conseil du roi de Louis XII á la Revolution (Paris, 1970), $5^{-13}$.

32 Guérin, Registres Paris, 1539-1552, 183.

33 AD Seine-Maritime, AM Rouen, A 16, fol. 172r.

34 Bertoldi, 'Entrées des rois à Angers', 314.

35 Bernard Barbiche, Les institutions de la monarchie française à l'époque modern XVI ${ }^{e}-X V I I I^{e}$ siècle (Paris, 1999), 37-38; Chatenet, Cour de France, 6-38. 
Évreux in 1485 , the échevins paid 35 sous to the porters of the castle to give them access to the building 'to make their supplications and requests to the king. ${ }^{36}$ Having the support of royal officials was particularly important from the mid-sixteenth century, when municipal councils found it increasingly difficult to procure entry to the king's lodgings. From the reign of Henry II, the French Crown adopted increasingly restrictive measures to regulate access to the monarch's chambers when he was on progress. In advance of Charles IX's entry into Bergerac in July 1565 the maréchal des logis (who oversaw the preparation of the king's quarters when he was on progress) instructed the consuls to construct a separate staircase at the monarch's lodging for his personal use. This meant that even if the townspeople managed to gain entry to the king's residence, they would not be able to enter the monarch's rooms without the assistance of royal officials. ${ }^{37}$ Staircases were constructed in royal palaces as a ceremonial space that was designed to accentuate the majesty of the king. As well as permitting the king's officials to restrict entry to his chambers to all but the most intimate of guests, it also allowed the monarch to utilise the vertical dimension of the staircase to highlight his superior status when receiving dignitaries. ${ }^{38}$ By constructing temporary staircases when on progress, royal officers maintained the distance between the king and his subjects that changes to the design of royal palaces had established in the mid-sixteenth century. Possibly acting in imitation of royal trends in palace design, municipal councils also began to construct temporary staircases so that they could control access to the king and queen. For the entry of Henry II and Catherine de Medici into Paris in 1549, the échevins invited the queen to a banquet at the residence of Cardinal Jean du Bellay, where they hoped to win her support through the provision of gifts. In order to control Catherine's progress to the

36 M. Benet, 'Louis XI à Evreux', Bulletin de la société de l'histoire de Normandie 7 (1893), 170.

37 G. Charrier, ed., Les jurades de la ville de Bergerac tirées des registres de l'Hôtel de Ville, 4 vols (Bergerac, 1892-83), i. 278-79, 282-83. For this entry see also: Bergerac. Ses hôtes illustres, Charles IX, Roi de Navarre, Louis XIII, Félix Faure (Bergerac, 1895), 39-41; Victor E. Graham and W. McAllister Johnson, eds., The Royal Tour of France by Charles IX and Catherine de' Medici: Festivals and Entries, 1564-6 (Toronto, 1979), 121.

38 Chatenet, Cour de France, 254-56; Mary Whiteley, 'Royal and Ducal Palaces in France in the Fourteenth and Fifteenth Centuries: Interior, Ceremony and Function', in Jean Guillaume, ed., Architecture et vie sociale: l'organisation des grandes demeures à la fin du Moyen Âge et à la Renaissance (Paris, 1994), 48-49; idem, 'Deux escaliers royaux du XIV e siècle: "les grands degrez" du Palais de la Cité et "la grande viz" du Louvre', Bulletin Monumental 147 (1989), 133-42; Jean Guillaume, 'L'escalier dans l'architecture française de la première moitié du XVIe siècle', in André Chastel and Jean Guillaume, eds., L'escalier dans l'architecture de la Renaissance (Paris, 1985), 27-47. 
banqueting hall from Notre Dame, the échevins built a staircase leading from the doors of the cathedral directly to the residence of du Bellay. Although this was a considerable undertaking, which involved constructing a bridge across the Seine, it allowed the municipal council to control the movements of the queen and deny rival groups and individuals from accessing her. ${ }^{39}$

In the absence of a royal palace, kings customarily stayed in religious buildings, including abbeys and episcopal palaces. In these situations, municipal councils had little control over the king's lodgings. When Louis XII entered Mâcon in 1501, for example, his rooms were prepared by the doyen of the cathedral of Saint-Vincent, with no input from the échevins. ${ }^{40}$ Although the town council was spared the financial expense of hosting the king, this situation was ultimately to the échevins' detriment because it limited their access to those in power. Fundamentally, control of royal lodgings allowed communication with the monarch. When Henry II entered Lyon in September 1548, Archbishop Ippolito d'Este vacated the episcopal palace for the king and queen. Nonetheless, the archbishop kept an apartment in the building, allowing him to remain in close proximity to the monarch. When Henry's fourriers decided to expel the archbishop from his apartment, d'Este was able to reverse the decision by using the access he had to the royal lodgings to appeal directly to the king. ${ }^{41}$

Yet as urban jurisdiction did not extend to episcopal palaces, gaining admittance to the monarch's rooms could be difficult. In an attempt to establish some control over Louis XI's residence Beauvais' municipal council worked with members of the clergy to prepare the lodgings for king and his entourage. ${ }^{42}$ Urban governments also exploited friendly relations with cathedral authorities to gain admittance to the king's rooms. When Louis XI entered Tournai in 1463, he lodged at the house of the cathedral canon, Jean Manich, rather than at the

39 Guérin, Registres Paris, 1539-1552, 180-81. C'est l'ordre et forme qui a este tenue au sacre [et] couronneme $[n]$ t de treshaulte [et] tresillustre dame, Madame Catherine de Medicis, royne de France (Paris, 1549), p. 35 .

40 Aм Mâcon вв 22, fols. 89v-92r.

41 Cooper, Entry of Henry II into Lyon, 26. While d'Este had influence with Henry II in 1548, this was lost the following year: Cédric Michon, 'Hipployte d'Este (1509-1572)', in Michon, Conseillers de François I ${ }^{e r}$, 532. For d'Este, see: Mary Hollingsworth, The Cardinal's Hat: Money, Ambition and Housekeeping in a Renaissance Court (London, 2004); Jean Tricou, 'Un archevêque de Lyon au XVI e siècle, Hippolyte d'Este', Revue des études italiennes (1958), 147-66. 
episcopal palace (the traditional residence for visiting monarchs).$^{43}$ This benefited Tournai's échevins, who were on good terms with Manich. The canon had already acted as a peace broker between the monarch and the civic councillors, who had refused to support Louis's rebellion against his father in 1440. During the king's visit to Tournai, Manich brought the échevins into Louis's presence, allowing them to offer their gifts to the king and petition him for new liberties. ${ }^{44}$ In the same way that civic administrations enlisted the support of the clergy to deliver the municipal harangue at the extramural greeting, they needed to negotiate with religious authorities in order to gain access to the king when he stayed in religious buildings.

As we saw with Louis XI's actions at Tournai in 1463 , kings could decide to stay in lodgings of their choice rather than in traditional royal residences. French monarchs rarely lodged with commoners before the mid-fifteenth century, yet Charles viI opted to stay at bourgeois' residences following his entries. His choice of accommodation was a consequence of the political instability of the 1420s, when the Lancastrian monarch ruled large swathes of France and Charles viI's support base had shrunk considerably. During this period, the Valois king became increasingly paranoid and preferred to stay with trusted followers such Martin d'Agougues at Tours and Jean Boucher at Orléans, both of whom were royal financial officers. ${ }^{45}$ With the resurgence of Valois power after 1429, there were other reasons to lodge with townspeople. When Charles entered Caen in 1450, he chose to stay with a prominent merchant. ${ }^{46}$ Given that Caen had been under English control for the past thirty years, the king's decision to lodge with one of its leading families allowed him to re-establish links with the town's rulers. Charles's choice of residence during his entries formed part of the monarchy's efforts to develop an entente cordiale with urban elites. When Charles viI entered Limoges in 1439, he lodged with the draper Guillaume Julien, whose family dominated the town's government during the

43 During his northern progress of 1463 Louis also opted to stay at the house of a canon at Arras rather than with the bishop. Likewise, when he entered Abbeville, he lodged with Jean Vilain, his advocate in Ponthieu: 'Continuator of Monstrelet', in Thomas Johnes, ed., The chronicles of Enguerrand de Monstrelet, 12 vols (London, 1810), x. 154; BNF Collection Picardie 37, p. 282. Louis XI stayed at bourgeois residences throughout his reign: P.-R. Gaussin, Louis XI, roi méconnu (Paris, 1978), 412.

44 Guenée and Lehoux, Entrées royales françaises, 194, 198; Douët-d'Arcq, Chronique de Monstrelet, x. 157 .

45 Dauphant, Royaume, 79; Bernard Chevalier, Tours, ville royale, 1356-1520: origine et développement d'une capitale à la fin du Moyen Age (Louvain, 1975), 222.

46 'Continuator of Monstrelet', in Johnes, Monstrelet, ix. 132. 
fifteenth century ${ }^{47}$ The Juliens had almost unfettered access to the king during his visit to the town, which allowed them to promote the family's position. This was a two-way process and the positive effects of Charles's attempts to build up links with urban administrations during his entries were manifested during the princely revolt known as the Praguerie (1440), when municipal governments overwhelmingly gave their support to the Crown against the rebel princes. ${ }^{48}$ There was also symbolic capital in staying at a bourgeois' residence. Two months after Francis, duke of Guise, recaptured Calais in January 1558, Henry II made his inaugural entry into the town. Before its conquest, Calais was a centre of commerce. Yet the French monarch entered a ghost town, as the population had crossed the Channel (England controlled Calais from its conquest by Edward III in 1347 right through to its loss by Mary in 1558). Henry II decided to stay at the former house of a wealthy English merchant, which one eyewitness called 'the most beautiful and best decorated in all the city.49 This merchant's house was symbolic not only of Henry's achievement in retuning Calais to French rule after two hundred years of foreign domination, but also of a decade spent extending the frontiers of France. ${ }^{50}$ As these examples highlight, while French monarchs could limit their contact with townspeople by staying in royal or episcopal buildings, political considerations could induce them to stay in bourgeois residences.

Municipal councils were also obliged to provide lodgings to members of the king's entourage. This could work to the advantage of urban governments as it allowed them to gain access to the most influential members of the royal household. As we shall see in chapter three, it was crucial for municipal councils to secure the support of those who travelled with the king in order to have their grants confirmed. Towns were divided into different sections, with each section given over to one of the principal nobles who travelled with the king. When Charles VI entered Tournai in 1382, the city was divided into four sectors to lodge the dukes of Berry, Bourbon, Burgundy and the constable of France (Olivier de Clisson), as well as their entourages, while the king and

47 Jean Tricard, 'Mariage, “commérages", parrainage: la sociabilité dans les livres de raison limousins du XVe siècle', in Croyances, pouvoir et société (Treignac, 1988), 137; Jean Tricard, 'Le consul, le moine et le roi: entrées royales et antagonismes urbaines à Limoges au XVe siècle', in Patrick Boucheron, ed., Religion et société urbaine au Moyen Âge, études offerts à Jean-Louis Biget (Paris, 2000), 406.

48 Chevalier, Bonnes villes, 101.

49 Léon Pollet, 'L'entrée d'Henri II à Calais en 1558', Bulletin de la commission des Monuments historiques du Pas-de-Calais 7 (1956), 549.

$5^{0}$ As well as re-taking Boulogne (1550) and Calais (1558) from the English, Henry II also conquered Metz, Toul and Verdun from the Empire in $155^{2}$. 
his household stayed in the abbey of Saint-Martin (the traditional royal residence in the city)..$^{51}$ As the size of royal entourages grew significantly during the fifteenth century, it became necessary for townspeople to give over rooms in their houses to the king's followers. While Charles viI was installed in the archiepiscopal palace following his entry into Rouen in 1449, the members of his entourage were placed in the very best houses in the city. Although Mathieu d'Escouchy tells us that the Rouennais received their noble guests with 'good cheer', townspeople frequently resisted the billeting of nobles in their homes because of their unruly and often violent behaviour. ${ }^{52}$ Following Louis XII's entry into Amiens in 1513, a number of townspeople who had been mistreated by the nobles staying with them went to the royal prévôt to receive compensation. ${ }^{53}$ As well as harassing their hosts, members of royal entourages also damaged the property of bourgeois families. After the entry of Mary of Guise into Amiens in 1551, numerous townspeople came to the municipal council seeking compensation for broken beds and damaged linen (for example, one Simon Pointel complained that one third of the mattresses he had provided for the dowager queen of Scotland and her entourage had been lost). ${ }^{54}$ Although municipal councils used the access they had to the members of royal entourages lodged in bourgeois houses to help them obtain new grants from the king, the disorder nobles and officials created did not encourage townspeople to willingly give over rooms in their residences for this purpose. Moreover, the general population frequently did not benefit from the petitions the elite put to the king following the entry, many of which were designed to shore up the elite's dominance of the town at the expense of other urban groups. As such, rather than creating cohesion and harmony between urban social groups, an entry frequently led to the creation of resentment and hostility between municipal elites and the general population.

51 A. Hocquet, ed., Croniques de Franche, d'Engleterre, de Flandres, de Lile et espécialement de Tournay (Mons, 1938), 255.

52 Beaucourt, Chronique de Mathieu d'Escouchy, i. 242. For unruly nobles see: R. J. Knecht, 'The Court of Francis I', European Studies Review 8 (1979), 14-15; Robert A. Scheider, Public Life in Toulouse 1463-1789: From Municipal Republic to Cosmopolitan City (Ithaca and London, 1989), 30; M. G. A. Vale, 'Provisioning Princely Households in the Low Countries during the pre-Burgundian period, c.1280-1380', in Werner Paravicini, ed., Alltag bei Hofe: 3 . Symposium der Residenzen-Kommission der Akademie der Wissenschaften in Göttingen (Sigmaringen, 1995), 39.

53 AM Amiens AA 12, fol. 113r.

54 Aм Amiens в в 27, fol. 8or. For further complaints from the townspeople, see: вв 27, fols, 73r, 87r, $111 \mathrm{r}$. 
Given the problems associated with lodging members of royal households, municipal councils often had to compel townspeople to host nobles and officials during a royal visit. In advance of Louis XII's entry into Mâcon in 1501, the échevins instructed the townspeople to receive their guests well and without complaint. ${ }^{55}$ However, it was not always possible for municipal governments to lodge members of royal households with urban populations. During the fifteenth century, the people of Paris obtained an exemption from the obligation to lodge members of the king's entourage. When Charles VII entered Paris in 1437, he confirmed the cathedral chapter's right to forbid members of the king's, queen's and dauphin's households from lodging in the cloister of Notre Dame. ${ }^{56}$ These rights posed little threat to the lodging of royal entourages in the fourteenth and early fifteenth centuries because Paris had numerous inns where the members of royal entourages could stay. Furthermore, as France's principal nobles possessed residences in Paris (as did royal officials), the citizens' exemption from housing members of the king's entourage was of minimal concern to the municipal government and the royal quartermasters (fourriers), who organised the preparation of the king's chambers when he was on progress. However, the political crises of the first half of the fifteenth century (particularly the civil war and the English occupation of northern France) led the Valois court to favour the Loire over Paris. The monarchy's abandonment of Paris impacted on the businesses that relied on the presence of the court, especially innkeepers. During the second half of the fifteenth century, a decline in the number of inns, combined with the rapid growth in the size of the Valois court, meant that Parisian rights to be exempt from lodging members of royal entourages became a source of increasing concern for both the municipal government and the king's household officers. The registers of the Parlement of Paris note that when Louis XI made his post-coronation entry into Paris in 1461, his followers 'could not be lodged in the inns of Paris because of the great diminution and little number of them... [a result of] the long time that the king and princes of the blood had neglected to make their residence and frequentation in the said town.' ${ }^{57}$ The Parisians exemption from lodging members of the royal entourage was of immediate concern to the city council which was planning Louis XI's entry. In order 'to avoid scandal and inconvenience',

55 Bazin, 'Rois de France à Mâcon', 66;

56 Guenée and Lehoux, Entrées royales françaises, 71. Likewise, in 1429, Charles VII exempted the bourgeois of Orléans from having to contribute towards the residences of the king and princes of the blood: P. Veyrier du Muraud et al., Ville d'Orléans. Inventaire sommaire des archives communales antérieures à 1790 (Orléans, 1907), 2. 
the échevins mobilised their sergeants to persuade the city's bourgeois to lodge royal officials, though these efforts met with little success. ${ }^{58}$ When the Valois court returned to Paris in the mid-sixteenth century, concerns about the lodging of royal entourages became pressing and the municipal council began to adopt methods harsher than persuasion. When Henry II made his inaugural entry into Paris in 1549, the civic council ruled that anyone who resisted lodging members of the king's entourage would be compelled to leave their house. ${ }^{59}$ The tokens used to mark out houses destined to receive guests became a source of tension between urban governments and the general population, who often tore them down. At Tournai, any townspeople caught removing the markers were to be 'punished as rebels' - one of the most serious crimes of the age. ${ }^{60}$ Municipal councils clamped down on resistance to the lodging of nobles because such confrontations harmed their efforts to gain access to the members of the king's entourage. When the population of Arras opposed attempts by Louis XI's fourriers to allocate houses to his followers in 1463 , the king forbade the people travelling with him from staying in the town. ${ }^{61}$ This limited the échevins' opportunities to gain access to those nobles who could promote municipal affairs with the king and his officials. The townspeople's actions were disastrous for Arras' municipal council, which was then attempting to rebuild its relations with the Valois monarch. As the échevins were unable to gain contact with the king's supporters, they found it difficult to acquire agents to intercede with the monarch on their behalf. Indeed, Louis delayed making his entry into Arras and kept the town council fearful that he would not confirm its liberties. ${ }^{62}$ Overall, it was important for municipal councils to win the support of those who travelled with the king so that he was amenable to receive their requests during the second harangue.

\section{The Second Harangue}

Municipal councils devised a second harangue to draw attention to the town's gifts and the king's obligation to reciprocate. These speeches instructed the monarch about the key qualities of kingship, particularly largesse. For

\footnotetext{
58 Chronique Scandeleuse, i. 24-25.

59 Guérin, Registres Paris, 1539-1552, 162.

6o La Grange, 'Entrées des souverains', 50.

61 'Continuator of Monstrelet', in Johnes, Monstrelet, x. 152.

62 A. Proyart, 'Louis XI à Arras', Mémoires de l'Académie des sciences, lettres et arts d'Arras 34 (1861), 107-8.
} 
example, when offering their gifts to Charles IX in 1564, Sens' échevins emphasised the king's responsibility to give generously. ${ }^{63}$ Although municipal councils hired professional speakers to deliver the extramural greeting, it was often the mayor, accompanied by the senior members of the municipal council, who delivered the second harangue. Furthermore, whereas the extramural greeting normally took place in a highly public setting, the second greeting was made in the king's chambers and involved a more restricted audience - typically the monarch, his closest advisors, and the municipal council. This exclusive encounter allowed urban elites to cement their relationship with the king by excluding others from the meeting. Municipal councils were composed of individuals drawn from the leading families of the town, which dominated civic governments for generations. ${ }^{64}$ To give one example, the male members of the Clabaut family filled the senior positions in Amiens' administration for two centuries. ${ }^{65}$ The participation of the principal members of these urban dynasties in the second greeting was important because the mayor petitioned the king for rights and liberties that were intended to strengthen the urban elite's mastery of municipal political, social and economic structures. While urban governments wanted the general population to prepare the entry and lodge the guests, they excluded them from the petitioning process. This is because the civic elite sought rights and privileges that were frequently to the disadvantage of other urban groups, such as the craft guilds. The elite's exclusion of these rival groups was especially important for the older urban dynasties, as many of their lineages had weakened during the later Middle Ages. In their place, new families (which had often immigrated into towns from the surrounding countryside as a result of the opportunities offered by post-Black Death changes to the urban economy) attempted to dislodge the entrenched civic elites from the upper echelons of civic governments. ${ }^{66}$ As a consequence of these broader social changes, royal entries provided the older municipal dynasties with an opportunity to reaffirm their dominance over urban power structures, while at the same time providing the new families that were seeking to control urban governments (but who lacked the pedigree gained through family lineage that was important for municipal office holding) to affirm their right to power by stressing their links to the Crown.

63 Vaillancourt, Entrées solennelles, Charles $I X, 79$.

64 David Nicholas, Urban Europe, noo-170o (Basingstoke, 2003), 99.

65 Auguste Omer Janvier, Les Clabault: familie municipale amiénoise, 1349-1539 (Amiens, 1889).

66 Nicholas, Urban Europe, 103. 
Civic elites both old and new used the second greeting to create an affiliation between their families and the king. The children of the mayor and other leading urban officials regularly participated in the gift presentation, which accompanied the offering of the town's petitions. The daughters of one of Mâcon's pre-eminent families presented the gifts to Henry II and Mary of Guise in $1548 .{ }^{67}$ When Charles Ix entered the town sixteen years later, three young women drawn from Mâcon's principal families were again chosen to present the town's gifts to the king. ${ }^{68}$ In other towns, such as Poitiers, the mayor's eldest son took part in the gift presentation. As urban dynasties dominated civic governments for years, the male children of elite families could expect to lead the municipal delegations that welcomed future kings of France. For this reason, royal entries promoted interaction between the king and successive generations of leading urban families, thus facilitating the construction of long-lasting attachments between civic leaders and the Crown. When Charles viII entered Poitiers on 15 February 1487, Geoffroy, the ten-year-old son of the mayor, Yves Boilesve, stood holding 'a fleur-de-lis signifying Poitiers' while his father delivered the second harangue and submitted the town's petitions to the king. This event provided the mayor's son with practical experience of the workings of the French state (indeed, Geoffroy sat on Poitiers' ruling council before becoming a member of the Parlement of Paris). ${ }^{69}$ Geoffroy Boilesve's career was typical of a new breed of bourgeois officials who, from the late fifteenth century, used their experience of civic government to obtain positions in the royal administration in a trend that Bernard Chevalier likened to 'a cancer in a healthy organism. ${ }^{70}$

Recent years have witnessed a move away from the influential reciprocity model of gift giving first proposed by Marcel Mauss and then developed by Marshall Sahlins and others. ${ }^{71}$ In his recent studies of urban gift giving Valentin

67 Bazin, 'Rois de France à Mâcon', 79-80.

68 Bazin, 'Rois de France à Mâcon', 84. For women presenting gifts see also: Boudet, 'Charles VII à Saint-Flour', 303; Gouvenain, Inventaire sommaire, Dijon, iii. 6.

69 Rivaud, Entrées princières, 123. Two members of the Boilesve family (Thomas and Jehan) had organized the gifts for Louis XI's entry in 1462: M. Rédet, 'Extraits des comptes de dépenses de la ville de Poitiers aux XIV et XVe siècles', Mémoires de la Société des antiquaires de l'Ouest 7 (1904), 445.

70 Chevalier, Bonnes villes, 129.

71 Marcel Mauss, The Gift: Forms and Functions of Exchange in Archaic Societies (London, 1954); Annette B. Weiner, Inalienable Possessions: The Paradox of Keeping-While-Giving (Berkeley and Oxford, 1992); Arjun Appadurai, ed., The Social Life of Things: Commodities in Cultural Perspective (Cambridge, 1986); Marshall Sahlins, Stone Age Economics (London, 2004). For an overview of how different historians have applied Mauss's theories see: 
Groebner has substituted reciprocity for uncertainty, writing it is evident that, in the moment of giving, the giver cannot openly claim any return, if he does not want to put the whole operation at risk. ${ }^{72}$ Likewise, in their study of gift giving in French royal entries Bruno Paradis and Lyse Roy (who follow Pierre Bourdieu) state that the king received post-entry gifts in return for having ratified urban privileges. ${ }^{73}$ In other words, the town waited until the conclusion of the entry to provide a gift in exchange for the ruler's confirmation of their liberties (which took place at the beginning of the entry) so that the two acts did not appear to be connected. However, when we examine the municipal documents relating to French entries, we find that town councils did not provide gifts in return for the confirmation of their current liberties. In fact, they were given in the expectation of winning new rights. As the king had already confirmed municipal liberties either during the extramural greeting or at court in advance of the entry, the gift exchange offered the town an opportunity to press for new liberties. For Louis XI's entry into Tournai, the municipal council decided that the gift presentation was the best time to make their requests to the king. ${ }^{74}$ By tendering their petitions to the king at the same time as they offered the gift, town councils indicated to the monarch what they hoped

Around-Jan A. Bijsterveld, 'The Medieval Gift as Agent of Social Bonding and Political Power: A Comparative Approach', in Esther Cohen and Mayke B. De Jong, eds., Medieval Transformations: Texts, Power, and Gifts in Context (Leiden, 2001), 126-37.

72 Valentin Groebner, 'Accountancies and Arcana: Registering the Gift in Late Medieval Cities', in Esther Cohen and Mayke B. de Jong, eds., Medieval Transformations: Texts, Power, and Gifts in Context (Leiden, 2001), 238. See also: idem, 'The City Guard's Salute: Legal and Illegal, Public and Private Gifts in the Swiss Confederation around 1500', in Gadi Algazi, Valentin Groebner and Bernhardt Jussen, eds., Negotiating the Gift: Pre-Modern Figurations of Exchange (Göttigen, 2003), 248-49.

73 Bruno Paradis and Lyse Roy, “Le cueur craintif est de tout danger seur, puisque Titan en ce pays arrive". Le don dans les entrées solennelles en France aux XV et XVI ${ }^{\mathrm{e}}$ siècles', in Marie-France Wagner, Louise Frappier and Claire Latraverse, eds., Les jeux de l'échange: entrées solennelles et divertissements $d u X V^{e}$ au XVII siècle (Paris, 2007), 109; Pierre Bourdieu, Practical Reason: On the Theory of Action (Stanford, 1998), 94. See also: Florence Migneault, 'Bon vouloir et affection: don et réciprocité dans les entrées rouennaises du XVIe siècle', Cahier du Groupe de recherches sur les entrées solennelles (2003), 20-21. Also following Pierre Bourdieu's influential work on gift giving, in his study of ceremonial entries in the Low Countries Mario Damen asserts 'it is important that the gifts were not handed over during the welcome of the prince outside the city's gates but only after the oath ceremony had taken place': Mario Damen, 'Princely entries and gift exchange in the Burgundian Low Countries: a crucial link in medieval political culture', Journal of Medieval History 33 (2007), 234.

74 Guenée and Lehoux, Entrées royales françaises, 188. 
to receive in return for their generosity. Certainly, there was an explicit link between the offering of gifts to the king and the granting of new urban liberties. When Francis I entered Troyes in 1521, the silver statue the municipal council had commissioned for the king was not ready by the time of his departure. Once the item was finished, the échevins sent deputies to Dijon to present it to the monarch. As soon as Francis received the town's gift, he immediately granted the petitions the municipal council had put to him at the entry, which included the right to hold a new fair and to levy a salt tax. ${ }^{75}$ By delaying his confirmation of the town's petitions until he had received the silverware, Francis underscored the explicit correlation between gift and counter-gift.

Historians have also downplayed the economic benefits of entries for townspeople. In his study of gift giving at Burgundian ceremonial entries, Jesse Hurlbut states that 'in material terms alone, the first entry constituted an exchange that was always to the disadvantage of the city.' ${ }^{36}$ Yet Hurlbut linked the gift giving to the extramural confirmation of liberties, when the offering of gifts was actually tied to the winning of new rights that went beyond those ratified at the extramural greeting. Although French municipal councils spent prodigiously on the king's gifts, the grants they received in return provided long-lasting financial rewards that outweighed the expense of an entry. Indeed, the king was expected to meet with civic administrations and grant them substantial new privileges at an entry. When Charles vi returned to Paris after his coronation at Reims in 1380, Jean Juvénal des Ursins tells us that the monarch avoided making the customary entries into northern towns so as to avoid receiving requests regarding the aides (a tax on goods). ${ }^{77}$ In other words, Charles bypassed these towns because custom would have bound him to authorise urban requests for tax reduction at his entries. ${ }^{78}$ As the granting of petitions was a fundamental part of an entry, they were issued even when

75 Babeau, Rois de France à Troyes, 33-35.

76 Jesse Hurlbut, 'The duke's first entry: Burgundian inauguration and gift', in K. M. Ashley and W. Hüsken eds., Moving Subjects: Processional Performance in the Middle Ages and the Renaissance (Amsterdam, 2001), 173.

77 Guenée and Lehoux, Entrées royales françaises, 58.

78 Increasing taxation was one of the main features of Charles v's reign, so much so that on his deathbed he abolished the hearth tax (fouages). While Charles VI was able to avoid abolishing the aides at his entries, popular resistance to these taxes at the beginning of his reign soon compelled him to do so: Autrand, Charles VI, 73-88; F. Chatillon, 'Charles V "Nummularius" et l'abolition des fouages', Revue du Moyen Age Latin 1-2 (1964), 112-14; H. A. Miskimin, 'The Last Act of Charles V: The Background of the Revolts of 1382', Speculum 38 (1963), 433-42; Peter Lewis, Later Medieval France: The Polity (London, 1968), $105^{-6 .}$ 
townspeople were not in royal favour. Although Charles viI delayed his entry into Paris to show his displeasure at the city's support for the Lancastrian monarchy, when he entered his capital in 1437 he granted the requests brought to him by the town council, the Parlement and the University. ${ }^{79}$ The conferring of these rights is especially significant when we remember that the municipal government, the Parlement and the University had all supported the claims of Henry V and Henry vi to the throne of France. Despite Charles's ill feeling towards the Parisians, the awarding of these requests formed part of the monarch's efforts to legitimise his rule. It was a mark of royal power to be able to grant a request, and the fact that the Parisians were petitioning him, rather than the Lancastrian monarch, was recognition of his right to rule from the city's principal institutions. Overall, municipal councils used gift giving as a means to significantly expand their power by persuading the monarch to furnish them with financially and politically rewarding new rights, which went beyond those set down in the urban charters he confirmed either during the extramural greeting or in advance of his entry. In order to ensure that they capitalised on a royal visit by winning new rights, urban governments had to ensure they offered suitable gifts to the king.

\section{The Gifts}

While the obligation to offer gifts may have developed from the early medieval royal right of gite (which required townspeople to provide the king and his entourage with victuals and lodgings), the provision of victuals also reflected urban cultural practices, as food and drink were frequently exchanged between members of the municipal elite. ${ }^{80}$ Urban governments also offered liquid gifts when seeking to obtain the services of a broker to promote their affairs at court. ${ }^{81}$ There was a biblical precedent for the offering of gifts of food and

79 Guenée and Lehoux, Entrées royales françaises, 75.

80 Cyrille Chatellain, 'La maïeur et les échevins d'Amiens à table (1385-1483)', Publications $d u$ Centre Européen d'études bourguignonnes 47 (2007), 169-88; M. Mathon, 'Le droit de gîte du roi saint Louis à Beauvais', Mémoires de la Société académique d'archéologie, science et arts du départment de l'Oise 6 (1865), 656; M. Facinger, 'A Study of Medieval Queenship: Capetian France, 987-1237', Studies in Medieval and Renaissance History 5 (1968), 26; Élodie Lecuppre-Desjardin, La ville des cérémonies: essai sur la communication politique dans les anciens Pays-Bas bourguignons (Turnhout, 2004), 121; H. Richardot, 'Le fief roturier à Toulouse', Revue historique de droit français et étranger 14 (1935), 315-16.

81 Davis, The Gift, 58; M.-A. Arnould, 'Lorigine historique des pots-de-vin', Bulletin de la classe des lettres et des sciences morales et politiques de l'Académie royale de Belgique 62 (1976), 
wine to the powerful in order to construct friendly relationships and obtain their patronage. Melchizedek offered gifts of bread and wine to Abraham, while Abigail offered David gifts of food and wine to gain his favour. ${ }^{82}$ As wine was the principal high-status drink of the age, large amounts of it were given to the king at an entry. When John II entered Tournai in 1355, the town offered him two pipes of Grenache wine, two pipes of Rhenish wine, four barrels of French wine and one barrel of red wine of Saint Jehan, which was produced in the region. As the wine was presented to the king in nine casks each bearing a mark identifying its provenance, the king could see that the municipal council was providing him with high-quality wines from across the kingdom and beyond. ${ }^{83}$ In addition to displaying the city's generosity, the échevins could also advertise the extent of their trading connections, which encompassed France, the Holy Roman Empire and the Low Countries.

The gifting of foodstuffs highlighted the scope of a town's economic and political networks. The small southern town of Béziers provided Francis I with goods from the Spanish kingdoms, demonstrating that it was involved in international trade despite its modest size - and thus of economic value to the king. ${ }^{84}$ Large commercial centres such as Lyon, Paris, Rouen and Toulouse obtained an abundance of exotic foods to offer as gifts, with the quantity and range of foods corresponding to the guest's social status. ${ }^{85}$ When the dauphin, Francis, entered Paris in $155^{2}$ the municipal council gave him a range of luxury foodstuffs, including numerous spices. ${ }^{86}$ This was an attractive gift, as royal households consumed vast quantities of spices. ${ }^{87}$ As well as highlighting

227-55; Marc Boone, 'Dons et pots-de-vin, aspects de la sociabilité urbaine au bas Moyen Age: le cas gantois pendant la période bourguignonne', Revue du nord 70 (1988), 471-87; Alain Derville, 'Les pots-de-vin dans le dernier tiers du XVe siècle (d'après les comptes de Lille et de Saint-Omer)', in W. P. Blockmans, ed., 1477: Marie de Bourgogne. Le privilège general et les privilièges régionnaux de Marie de Bourgogne pour les Pays-Bas (Courtrai, 1985), 449-69. See also: Valentin Groebner, Liquid Assets, Dangerous Gifts: Presents and Politics at the End of the Middle Ages, trans. Pamela E. Selwyn (Philadelphia, 2002).

82 Davis, The Gift, 98-99.

83 La Grange, 'Entrées de souverains', 27-28.

84 Domarion, Entrée François Ier, Béziers, 14.

85 For the social status attached to different foods and spices, see: Bruno Lauroiux, Une histoire culinaire du moyen âge (Paris, 2005), 183-239.

86 Guérin, Registres Paris, 1539-1552, 293.

87 Laurioux, Histoire culinaire, 170-71, 183-96; Leslie G. Matthews, 'King John of France and the English Spicers', Medical History 5 (1961), 65-76. See also: Raymond van Uytven, 'Showing off One's Rank in the Middle Ages', in Antheun Janse and Wim Blockmans, eds., 
Paris's status as a commercial centre, the provision of expensive spices and other exotic goods presented its municipal council with an opportunity to submit petitions for privileges that would enable the city to consolidate its dominant economic position in the kingdom. Furthermore, Paris's échevins gifted spices to a range of visiting dignitaries, such as the imperial ambassadors who entered the city in $1500 .{ }^{88}$ Accordingly, the échevins were able to show visitors from across Europe that Paris was a leading commercial centre with international trading links. Not all French towns were able to procure, or afford, exotic gifts. Smaller towns tended to offer more modest items such as fish. All towns offered the king basic goods such as wheat, grain and candles to provide for the needs of the monarch and his entourage. When Charles viI entered Lyon on 16 June 1434, the king was presented with 50 livres of spices, 72 torches and 300 bushels of grain. According to the account made by a cathedral canon who witnessed the gift presentation, as soon as Charles left the room the goods 'were devoured by people of his entourage' especially the fifty boxes of spices. ${ }^{89}$ As spices were extremely expensive, they lay beyond the financial capabilities of most members of the royal household. By providing the king with the opportunity to be generous to his followers, the municipal council sought to encourage him to help the city generate the wealth it needed to provide expensive gifts such as spices.

Oxen were the centrepieces of the foodstuffs offered by municipal councils at royal entries in the fourteenth and fifteenth centuries. For example, Abbeville gave Charles viII three oxen that were harnessed and brought into the king's presence by three young women. ${ }^{90}$ Cattle were a traditional marker of prosperity, and the wealth of some urban elites (such as the rulers of fifteenth-century Montferrand) was derived from the sale of these animals. ${ }^{91}$ Furthermore, cattle were a feature of urban festivities (such as the fête des

Showing Status: Representations of Social Positions in the Late Middle Ages (Turnhout, 1999), 24-29.

88 Bonnardot, Registres Paris, 1499-1526, 52.

89 Guenée and Lehoux, Entrées royales françaises, 158; Louis Caillet, Étude sur les relations de la commune de Lyon avec Charles VII et Louis XI (1417-1483) (Lyon and Paris, 1909), 122-24.

9o Ledieu, 'Charles VIII à Abbeville', 59. The town planned to offer the same gift to Louis XI in 1477: Alcius Ledieu, 'Abbeville en Liesse. Réjouissances et fêtes publiques au XV'e siècle', Mémoires de la Société d'émulation d'Abbeville 20 (1901), 198. Urban governments went to considerable trouble to find the highest-quality oxen to present to king. When Charles vi and the dauphin entered Amiens with a large entourage in 1414, the échevins sent a butcher to search neighbouring villages for the best animals and then paid him look after them for ten weeks: Aм Amiens в в 2, fols. 49r-49v.

91 Graeme Small, Late Medieval France (Basingstoke, 2009), 190-91. 
merveilles in Lyon) and shooting confraternities competed for oxen in regional tournaments. ${ }^{92}$ During royal entries, these animals were offered to the king with great ceremony. When John II entered Tournai in 1355 a civic official presented him with three oxen covered in a red fabric that had been embroidered with the city's arms. Seated on each animal, was a page dressed in the town's livery. ${ }^{93}$ While some towns provided gifts of oxen at entries right through to the sixteenth century, the custom began to fall out of fashion during the second half of the fifteenth century. Municipal councils had traditionally offered animals to the king so that he could use them to feed his servants during the visit. However, the expansion in the size of the French king's household from the mid-fifteenth century meant that cattle no longer covered his needs. When Louis XI entered Évreux in 1462, the town council presented him with the customary ox. Whereas previous monarchs had ordered their servants to slaughter the animal for consumption by the royal household, Louis left it in Évreux. The monarch's actions posed a problem for the municipal council: as the ox now belonged to the Crown, it could not be killed or sold. Instead, the animal had to be maintained at Évreux's expense for several years, draining funds from the urban budget. ${ }^{94}$ By the time of Francis I's entry into Évreux in 1517, the town council had stopped offering oxen to the monarch; instead, it provided the king's household staff with cash payments to cover their living costs (see chapter three).$^{95}$ Furthermore, by the mid-sixteenth century, the presentation of a living animal was not deemed appropriate for the dignity of the French king and it is difficult to imagine Charles XI or Henry III accepting a gift of cattle from the hand of an urban deputy. The later Valois monarchs expected to receive items of silverware instead of animals. While ornamental objects such as plates or vases were offered to kings at royal entries from the fourteenth century, the presentation of these items became more common from the later

92 A. Péricaud, ed., Notes et documents pour servir à l'histoire de Lyon 1350-1485 (Lyon, 1839), 12; Jacques Rossiaud, 'Les rituels de la fete civique a Lyon, XII ${ }^{\mathrm{e}}-\mathrm{XVI} \mathrm{I}^{\mathrm{e}}$ siecles', in Jacques Chiffoleau, Lauro Martines and Agostino Paravicini, eds., Riti e rituali nelle societa medievali (Spoleto, 1994), 286-94.

93 La Grange, 'Entrées des souverains', 28. See also Amiens' presentation of oxen to the dauphin, Louis, in 1443: AM Amiens CC 31, fols. 72v, 74r. Animals were given as entries across the kingdom from the fourteenth century. For example, when Charles vi entered Lyon in 1389 he was given oxen and sheep: Albert Champdor, Les rois de France à Lyon (Lyon, 1986), 12.

94 Benet, 'Louis XI à Evreux', 174.

95 AM Évreux CC 52, n. 82. 
fifteenth century, which went hand-in-hand with a decline in the presentation of live animals. ${ }^{96}$

As Gordon Kipling has noted, the offering of silverware derived from the medieval act of 'feudal homage' and symbolised the town's recognition of its ruler. ${ }^{97}$ When Francis I entered Béziers in 1533, the municipal records note that he received a piece of silverware in form of recognition of our prince and natural lord. ${ }^{98}$ Yet despite its feudal origins, gift giving at royal entries went beyond a simple act of homage: it consolidated the relationship between the king and the urban elite by placing reciprocal obligations on both. ${ }^{99}$ Although the late-fifteenth century expansion in gift giving placed pressure on municipal budgets, urban administrations used the act to oblige the monarch to grant their petitions. Indeed, town councils offered gifts of silverware to the king even when they were not required to do so. Whereas the proffering of plates and vases was initially restricted to inaugural entries, by the sixteenth century French civic councillors offered silverware to kings who were entering a town for a second, or even a third time.

While historians typically downplay the importance of subsequent entries, we should also not assume that townspeople considered first entries to be the most significant. Louis XI's entry into Rouen in 1467 was arguably more important for the townspeople than his inaugural entry because of the value of new rights the city obtained on this occasion. ${ }^{100}$ Urban elites deemed second (or even third) entries to be as important as the king's first entry because it provided them with the means to use gift giving to win new liberties. Although urban administrations were not bound by custom to offer gifts at subsequent entries, the presentation of these items provided civic councillors with access to the king and required him to reciprocate. Failure to offer a gift could mean

96 When John II made his inaugural entry into Paris in 1350, the municipal council offered him an item of silverware: R. Delachenal, ed., Chronique des règnes des Jean II et de Charles V, 4 vols (Paris, 1910-20), i. 331. For gifts of silverware during entries in the fourteenth century, see also: Léon Mirot, 'Les cadeaux offerts à Charles VI par les villes du royaume', Bibliothèque de l'École des Chartes 101 (1940), 220-24.

97 Kipling, Enter the King, 115-16. Joël Blanchard, 'Les entrées royales: pouvoir et représentation du pouvoir à la fin du Moyen Age', Littérature 50 (1983), 6. For medieval rituals of vassalage see: Jacques Le Goff, 'Le rituel symbolique de la vassalité', in Jacques Le Goff, Pour un autre Moyen Âge: temps, travail et culture en Occident (Paris, 1977), 349-420.

98 Domairon, Entrée François Ier, Béziers, 53-54.

99 Arnould-Jan A. Bijsterveld, Do ut des. Gift Giving, Memoria, and Conflict Management in the Medieval Low Countries (Hilversum, 2007), 7; Damen, 'Princely Entries', 235.

100 Laurrière, Ordonnances rois de France, xvi. 579-81; Beaurepaire, 'Six voyages de Louis XI', 306. 
civic councils were unable to recoup the expenditure of the festivities by winning new grants. When Grenoble's consuls learnt in October 1537 that Francis I intended to enter the city for the third time, they decided not to provide him with any gifts of silverware due to the financial difficulties the city was suffering (indeed, the municipal council had to borrow the sum of 800 écus from the most prominent citizens of the town in order to pay for the silver helm they offered the dauphin at his entry earlier that month). As Francis had first entered Grenoble in 1515, the consuls were not obliged to offer him items of silverware; however, their failure to do so meant they lost the opportunity to present him with a request for tax exemption. As a result, the town had to send its representative, Paul Simon, to follow the court to try and pursue its petition with the monarch. ${ }^{101}$

The king expected to receive a gift that reflected the size and wealth of the town he was entering. It could be injurious for municipal councils to offer a gift the monarch deemed to be sub-standard, particularly because an unworthy gift did not bind him to reciprocate by offering grants. While Lyon was the second city of France in the sixteenth century, its municipal council spent only $75^{0}$ écus (1687 livres 10 sous) on the gift for Henry II, and 500 écus (1125 livres) on the gift for his wife, Catherine de Medici, in $1548 .{ }^{102}$ To put this in perspective, Rouen (a city ranked just below Lyon in the urban hierarchy of sixteenthcentury France) set aside 12,00o livres alone for the gifts it offered Henry and Catherine in $1550 .{ }^{103}$ Financial difficulties led Lyon's municipal council to curb its expenditure on the gifts to the king and queen in $1548 .{ }^{104}$ Despite the fact that Lyon's rulers had prepared a magnificent ceremonial entry for Henry and his wife (which included gladiatorial displays and naval combat on the Saône ${ }^{105}$ ), the city's efforts to save money by offering a gift that was unrepresentative of its status had dire consequences for the consuls. This testifies to the crucial role that gifts (rather than decorations) played in the winning of new rights for towns. Although Lyon's municipal council informed royal officials they had poured money into preparing magnificent entries for Henry and Catherine, the consuls' failure to ensure that they offered a suitable gift to the king and his wife nullified these efforts. It was imperative that towns offered

\footnotetext{
101 AM Grenoble B B 11, fol. 31r.

102 Ам Lyon вв 67, fols. 107r, 211v; Cooper, Entry of Henry II into Lyon, 16. This was less than a third of the value of the gift $(5,000$ livres) they had offered Louis XI at his entry in 1476 : Caillet, Relations de la commune de Lyon, 217.

103 For the urban hierarchy of sixteenth-century France, see: Chevalier, Bonnes villes, 41.

104 Ам Lyon вв 67, fol. 176r.

105 Guigue, La superbe et triumphante entrée, 3, 13.
} 
generous gifts to the king if they wanted the gift exchange to be profitable. ${ }^{106}$ Given the crucial role that gift giving played in the winning of new liberties, the failure of Lyon's ruling administration to obtain appropriate presents for the king and queen was a major oversight.

The inadequacy of Lyon's gift to Henry II in 1548 was underscored by the efforts of the city's Florentine merchants, who spent 5,000 livres (over three times the value of the municipal council's gift) on a silver statue for the king. ${ }^{107}$ The Florentines offered this costly statue to the monarch because they wanted to extend their commercial rights in the city. Whereas the Florentine merchants received new privileges from the French king in return for their gift, Lyon's consuls obtained nothing. As Henry II did not deem Lyon's gift to be of an adequate standard, there was no obligation for him to reciprocate. Lyon's failure to win new liberties highlights the crucial role gift giving played in the granting of petitions at royal entries. Other town councils attempted to make their gifts look more substantial than they actually were in order to inflate the extent of their generosity. When the consuls of Valence learned in May 1496 that Charles VIII (then returning from a successful campaign in Italy) planned to enter the town, they decided to offer him a silver cup with eight pieces of gold, each bearing the mark of the Dauphiné. However, the consuls resolved to use a small cup 'so that the coins were more apparent'. ${ }^{108}$ In other words, they tried to make the gift appear more substantial than it actually was, thus seeking to have their petitions granted while also reducing the expense of the entry.

Although Lyon's town council incurred Henry II's displeasure by offering him an inappropriate present, French kings did not expect all bonnes villes to offer gifts of equal value. When Francis I entered Toulouse in 1533, the city council spent 25,702 livres on the gifts alone, which represented $69 \%$ of the total costs of the entry. ${ }^{109}$ However, the governments of smaller towns did not have access to the financial resources of the principal cities of the kingdom to allow them to offer gifts on this scale. Béziers only raised 500 livres to purchase silverware for Francis I in $1533 .{ }^{110}$ Although this was only a fraction of the total value of the gifts he received at Toulouse, Francis deemed it appropriate for a town of its size. Likewise, when Louis XI entered the small Norman town of Pont-Audemer in December 1465, the ruling administration could only

\footnotetext{
106 Émile Benveniste, 'Don et échange dans le vocabulaire indo-européen', in Émile Benveniste, Problèmes de linguistique générale, 2 vols (Paris, 1974), ii. 322-23.

107 Cooper, Entry of Henry II into Lyon, 91.

108 Aм Valence в в 2, fol. 419r.

109 Paradis and Roy, 'Le don', 131.

110 Domarion, Entrée François Ier, Béziers, 22-23.
} 
afford one cask of good-quality red wine. While Louis received expensive gifts at his entries into larger towns on this progress through Normandy, he did not expect a town of fewer than three thousand inhabitants, lying in a region that was suffering persistent economic difficulties, to offer a gift that lay beyond its capabilities. As Louis deemed Pont-Audemer's single cask of good-quality wine to be a suitable present, he granted the municipal council the right to collect the profits from a tax levied on all the salt sold in the town for the next four years, even though the town had taken the side of the rebel princes in the War of the Public Weal. ${ }^{111}$ In some circumstances the king allowed a larger town to provide a less-expensive gift than he could normally expect. In advance of Francis I's entry into mid-ranking town of Angers in 1518, the governor of Anjou, René de Cossé, count of Brissac, wrote to the municipal council (which was then experiencing economic difficulties) stating that it would be sufficient for the town to offer only wine to the king. ${ }^{112}$ Yet such examples are rare and towns were normally expected to render gifts that reflected their position in the urban hierarchy.

Civic administrations also had to ensure that the scale of an entry corresponded to the status of their town, as kings did not confirm the liberties of places which had failed to provide a suitable welcome. Displeased with the entry he received at Grenoble in 1548, Henry II left the city without confirming its privileges or receiving petitions for new liberties. ${ }^{113}$ Grenoble's municipal deliberations reveal that the city was suffering from acute financial problems in the run up to Henry's entry. Its economic difficulties were exacerbated by the clergy's refusal to contribute to the cost of the elaborate entry staged in the previous month for Francis of Lorraine, the incumbent governor of Dauphiné. ${ }^{114}$ In addition, Grenoble's consuls did not expect Henry II to enter the city so soon after his coronation. The city council's decision to pour its financial reserves into the governor's entry left it unable to provide Henry II with the standard of entry he expected, and thus meant that the king did not feel bound to reciprocate.

In contrast to Henry's actions at Grenoble, French kings made additional grants to urban governments which produced entries that exceeded royal expectations. Henry II was so pleased with the reception Nantes provided him

\footnotetext{
111 This money was to be used to repair the town's fortifications: A. Canel, Histoire de PontAudemer, 2 vols (Pont-Audemer, 1885), ii. 28.

112 AM Angers B B 17, fol. 4r.

113 Denise Gluck, 'Les entrées provinciales de Henri II', L'Information d'histoire de l'art 10 (1965), 216; A. Prudhomme, Histoire de Grenoble (Grenoble, 1888), 337.

114 AM Grenoble B в 14, fols. 42r-43r.
} 
in 1551 that he instructed the Breton Cour des Comptes to reimburse the town council with the money it had spent on the entry. ${ }^{115}$ In exceptional circumstances, the king could permit one of the kingdom's leading cities to forgo the obligation to offer him an expensive gift. When Charles Ix entered Rouen in 1563, the échevins offered him a gift that cost 1,537 livres (they had spent almost ten times this sum on presents for his father in 1550). ${ }^{116}$ Charles allowed Rouen's leaders to provide him with a diminished gift because the city's fortunes had declined drastically in the decade since Henry II's entry into the city. In May 1562, Rouen's Protestants had seized control of the city. As a result of this insurrection, a royal army besieged and then sacked Rouen, crippling its already ailing economy. ${ }^{117}$ In consideration of the difficulties faced by the city's Catholic leaders (who were restored to power after the siege), Catherine informed the échevins in advance of the entry that her son the king was prepared to receive a less-expensive gift than was customary.118 The governor of Normandy, HenriRobert de La Marck, also wrote to Rouen's municipal council in advance of the entry to advise the échevins that both Charles and Catherine de Medici were sympathetic to the city's difficulties and they did not need go to unnecessary expense for the entry. ${ }^{119}$ Besides the diminished value of the gift, the overall character of the entry was on a scale far reduced to that staged for Henry II in $155^{\circ}$.

It was only in exceptional circumstances (such as the sack of a town) that the monarch permitted urban administrations to stage entries that fell short of what he could expect. The king did not deem the economic difficulties faced by the ruling councils of Grenoble and Lyon in 1548 to be sufficiently serious to allow their rulers to reduce the cost of his entries. It was crucial that municipal councils obtained the king's permission to provide an inferior reception in advance of his arrival. For this reason, urban rulers had to gain the support of those people who had great influence with the king in order to seek a reduction in the value of the gift. In advance of the entry of Henry III and Louise of Lorraine into Nevers in 1580, the échevins asked the king's brother, Francis, duke of Anjou, to ensure that the gifts they were obliged to provide did not

\footnotetext{
115 Gluck, 'Entrées provinciales', 216.

116 AD Seine-Maritime, AM Rouen A 18, fol. 103v.

117 For the background to this siege see: Philip Benedict, Rouen during the Wars of Religion (Cambridge, 1981), 49-70; Florence Migneault, 'Ruines et désolation: la mise en scène de Rouen dans les entrées royales de 1563 et 1596', Memini. Travaux et documents 5 (2001), 10-22.

118 AD Seine-Maritime, Am Rouen A 18, fol. 104r.

119 AD Seine-Maritime, AM Rouen A 18, fol. 104r; Paul Le Cacheux, ed., Entrée de Charles IX ̀̀ Rouen au mois d'aout 1563 (Rouen, 1936), x.
} 
exceed thirty pièces of wine. ${ }^{120}$ It was damaging to the monarch's honour to be received with an inferior ceremony or gift, especially during the sixteenth century when he travelled with foreign dignitaries who circulated reports of entries across Europe. In these circumstances, the king could punish the town by refusing to confirm its liberties or grant new ones. In contrast, if the monarch allowed a city council to receive him with a scaled-down reception, he could spread the news amongst his entourage in advance of an entry. Such a gesture could stand as an example of royal magnanimity and allow the town to continue to seek new grants from the king (which was a further example of example of the monarch's generosity to his urban subjects). However, under normal circumstances, urban governments were expected to provide the monarch and his family with a range of suitable gifts. While the monetary value and the quantity of these items was important, so too was their design.

\section{Designing the Gift}

Because gifts of silverware played a fundamental role in the winning of liberties, municipal councils discussed their design at great length. First of all, they established how much money they could spend on the items. Indeed, the cost of the silverware was commonly the greatest single expense incurred by municipal councils. When Charles viII entered Tours in 1484, 3,400 livres out of the entry's total cost of 4,000 livres was spent on the king's gift of silverware. ${ }^{121}$ In 1549, Paris's town council gifted Henry II a silver statue costing 10,00o livres, which the échevins reckoned to be the 'most beautiful item of work in all Europe.'122 Although the gifts of silverware were expensive, municipal councils hoped they would serve as lasting reminders of their generosity. While an entry ceremony was transitory, a tangible gift of silverware could survive in royal collections for generations. As many of the items of silverware were connected to drinking or eating (such as bowls, dishes or goblets), urban leaders were able to draw on the symbolism of the gifts of wine and food they provided at the meal as well as the sense of conviviality a banquet created. During the fourteenth and fifteenth centuries, the most common forms of silverware were plates or cups, although more elaborate items (such as saltcellars) were also offered.

120 François Boutillier, Ville de Nevers. Inventaire sommaire des archives communales antérieures à 1790 (Nevers, 1876), 5 .

121 AM Tours B B 13, fol. 2or; Rivaud, 'Entrées à Tours', 159.

122 Guérin, Registres Paris, 1539-1552, 181. For this gift see: George A. Wanklyn, 'Le présent offert à Henri II par la Ville de Paris en 1549', Revue de l'Art 46 (1979), 25-30. 


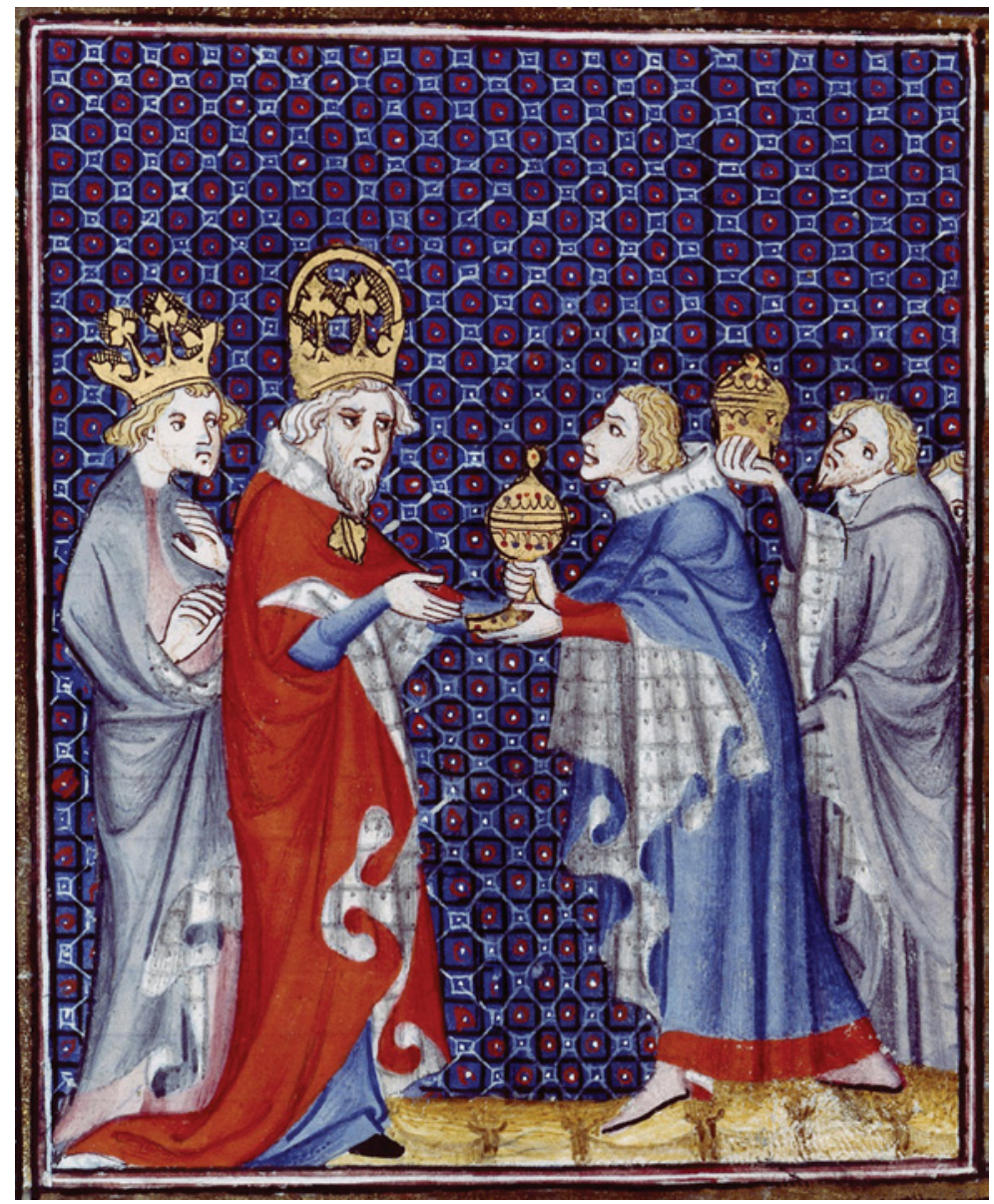

FIGURE 3 The presentation of gifts of silverware to King Charles $v$ of France and Emperor Charles IV following their joint entry into Paris in 1378. Bibliothèque Nationale de France 2812, FOL. $478 \mathrm{~V}$

As the gifts were of a similar design, municipal councils decorated them with civic emblems to remind the beneficiary of their town's generosity. Urban administrations hoped that the recipient of this gift would look at the item in the future and recall the entry fondly. Amiens' échevins engraved the town arms on the silver fountain they presented to Anne of Beaujeu in 1493 'so that the queen could... have memory of the gift for the good of this town'. ${ }^{123}$

123 AM Amiens B B 16, fol. 234r. 
By acting as reminder of the recipient's promises to act for the good of the town, gifts had a lasting power for urban governments.

By the sixteenth century, civic councils commissioned elaborate items of silverware which stood out from the more common forms of gifts. Rather than purchasing a cup or plate from a silversmith, urban governments began to employ a team of experts to produce an original item. Mâcon's town council hired the artist Robert l'Argentier to design Louis XII's gift, and the silversmiths Philibert Tramart and Jean de Lyon to make it. ${ }^{124}$ Urban governments hoped that a distinctive gift would remind the recipient of their obligations to the town. Paris's municipal council gave Eleanor of Austria a candlestick holder at her entry in 1531, symbolising (according to the municipal deliberations) her role as 'our light... [and] the principal reason for the peace, harmony and deliverance of messeigneurs [i.e. the town council].'125 In order words, the échevins wanted Eleanor to act as their intercessor, promoting the city's interests to her husband the king (see chapter three). Likewise, at the entry of Henry II and Catherine de Medici into Lyon in 1548, the Florentine merchants presented the queen with a golden fleur-de-lis, which was the emblem of both France and Florence, on the base of which was a representation of Florence looking to France for protection. The design of the gift illustrated the Florentines' expectation that in return for their generosity Catherine would persuade her husband to secure their dominant commercial position in Lyon. This design was effective, as Henry II extended Florentine trading privileges in the city. ${ }^{126}$

The Valois monarchs made regular progresses around their kingdom and received numerous gifts from townspeople. In order to devise items that appealed to royal tastes, municipal administrations employed artists who worked for the monarch. The rulers of Troyes hired Charles Colin, who had decorated the royal palace of Fontainebleau, to design their gift for Charles IX in $1564 .{ }^{127}$ Urban elites hoped that ornamental statues would stand out from the array of plates and cups the king received. When Péronne's municipal council gave Charles IX a statue of Hercules at his entry in 1564, the king immediately passed it around members of his court for them to admire. ${ }^{128}$ A distinctive gift could engage the king's attention. When Charles VIII entered Angers in 1487, the municipal council presented him with a pot made out of jasper. The town's

\footnotetext{
124 AM Mâcon B B 22, fols. 89v-92r.

125 Tuetey, Registres Paris, 1527-1539, 74.

126 Cooper, Entry of Henry II into Lyon, 92, 143.

127 Babeau, Rois de France à Troyes, 61.

128 BNF Collection de Picardie 54, fol. 228v.
} 
present charmed the king, who decided to keep it for himself despite having promised the item to Louis de La Trémouille, who had played a key role in securing Brittany for him. ${ }^{129}$ This jasper pot was so successful in promoting Angers to the Crown that the échevins attempted to repurchase it so that they could offer it to Francis I at his entry in $1518 .{ }^{130}$ As this example shows, the offering of a gift which appealed to the king's tastes meant that there was less of chance that it would be given it away. Urban governments could hope that it would remain on display in royal collections for many years and thus remind the king of the town's generosity and his obligation to respond in kind.

Some gifts were designed to articulate civic identity and act as a memory object. When Henry II entered Tours in 1551, he was given a silver statue representing Turnus, while his wife, Catherine, was given a statue of Lavinia. According to Roman mythology, Turnus, king of the city of Ardea, was the principal suitor for Lavinia, daughter of Lavinius, king of the Latins. More importantly for Tours' échevins, Turnus (a municipal king) was also the legendary founder of their city and it was believed that Aeneas had killed him just outside the town. By the later Middle Ages, Turnus was an emblem of civic identity for Tours and his death was depicted on the wall of the castle and during royal entries into the town. ${ }^{131}$ Furthermore, pilgrimage centres drew on local spiritual power when devising their gifts. For example, Tarascon gave golden images of Sainte Marthe at its entries. This early Christian martyr, who had converted the region's inhabitants to Christianity in the first century, was buried in Tarascon, where her body functioned as a symbol of local identity. ${ }^{132}$ In addition to their spiritual role, relics were also marks of urban wealth, with towns such as Amiens and Le Puy profiting from the influx of pilgrims (which included royalty). ${ }^{133}$ Amiens offered gifts of metal images of the head of Saint John the Baptist which was held in the city's cathedral. ${ }^{134}$ In order to highlight

\footnotetext{
129 AM Angers B B 5, fol. 8r.

130 Bertoldi, 'Entrées des rois à Angers', 312.

131 Rivaud, 'Entrées à Tours', 162-63, 173-74; Rigord, 'Vie de Philippe Auguste', in M. Guizot, ed., Collection des mémoires relatifs à l'histoire de France (Paris, 1825), 187; Kisha C. Tracy, 'Defining the Medieval City Through Death: A Case Study', in Albrecht Cassen, ed., Urban Space in the Middle Ages and the Early Modern Age (Göttingen, 2009), 187-88; C. Petitfrère, 'Réflexions sur la place du mythe dans l'histoire de Tours aux XVII e et XVIII e siècles', in A. Bartoli and G. Chaix, eds., La mémoire de la cité. Modèles antiques et réalisation renaissantes (Naples, 1997), 235-44.

132 Aм Tarascon в в 12, fol. 353r.

133 Small, Late Medieval France, 181; Roger Chartier et al, Histoire de la France urbaine, tome 3: la ville classique de la Renaissance aux Révolutions, ed. Georges Duby (Paris, 1981), 97-98.

134 Am Amiens B B 4, fol. 98 r.
} 
the close links that existed between the saint and Amiens, the municipal council had its arms placed on the statues. As these gifts connected both the recipient and the donor to noted saints, they added a further solemnity to the event and encouraged the beneficiary to promote the interests of the town in the future. ${ }^{135}$

Municipal councils moved away from designing gifts based on Christian imagery during the early sixteenth century, drawing instead on classical symbolism. This was part of a wider trend to produce entries informed by knowledge of ancient world, and the gifts were designed to accompany the thematic programme. As well as commissioning the poet Maurice Scève to plan the programme for Henry II's entry in 1548, Lyon's consuls also employed him to design the gift. ${ }^{136}$ Likewise, the gifts Rouen offered to Henry II and Catherine de Medici in $155^{\circ}$ complimented the classically inspired themes of their entries. ${ }^{137}$ The king was gifted a golden statue of Minerva and his wife received a golden statue of Astraea. ${ }^{138}$ Minerva was the goddess of learning, while Astraea represented the coming of a Golden Age, both of which were themes in the decorative programme of the entries. In other parts of France, the shift to classical imagery allowed municipal councils to emphasise civic identity. For example, by offering Louis XII a statue of Hector, Troyes' échevins referenced three important themes. First, it alluded to the legend that Troyes was founded by a group of Trojans who had escaped Agamemnon's sack of their city. Second, the gift referenced the myth of the Trojan origins of France. As Colette Beaune has shown, French kings used the Trojan myth 'to justify the independence of the kingdom from the papacy and the Germanic empire'. 139 Both of these claims were particularly important for Louis XII, who was then at war with the pope and the Holy Roman Emperor. Third, the offer-

135 Hurlbut, 'Inaugural Ceremonies', 110.

136 AM Lyon CC 987, no. 35 .

137 For the themes of this entry see: André Pottier, 'Entrée à Henri II à Rouen', Revue de Rouen 5 (1835), 29-43; Margaret McGowan, 'Form and Themes in Henri II's Entry into Rouen', Renaissance Drama 1(1968), 199-252; Victor E. Graham, 'The Entry of Henry II into Rouen: A Petrarchan Triumph', in K. Eisenbichler and A. Iannucci, eds., Petrarch's Triumphs, Allegory and Spectacle (Ottowa, 1990), 403-13; Michael Wintroub, 'Civilizing the Savage and Making a King: The Royal Entry Festival of Henri II', Sixteenth Century Journal 29 (1998), 465-94; idem, A Savage Mirror.

138 Am Seine-Maritime, Am Rouen A 16, fol. 117r.

139 Colette Beaune, The Birth of an Ideology: Myths and Symbols of Nation in Late-Medieval France, trans. Susan Ross Hudson (Oxford, 1985), 231. For the Trojan myth of the foundation of French cities see: Jean Tricard, 'Limoges entre Troyens et Géants: les origines mythiques d'une ville', in Bartoli and Chaix, Mémoire de la cité: Modèles, 161-70. 
ing of a statue of Hector allowed the rulers of Troyes to place their city at the forefront of new trends in the design of royal entries. ${ }^{140}$ While Troyes' could only draw on legends surrounding its foundation, the ancient Greeks and Romans had established towns and cities in the south of the kingdom, such as Arles, Marseille, Nîmes and Orange. These towns possessed physical remains attesting to their antiquity, which they incorporated into royal entries. When Francis I visited Arles in 1533, the town council brought a sarcophagus from the town's Roman necropolis (the Alyscamps) to his lodgings, while Charles Ix left Arles in 1564 with Roman arches and columns in his baggage. ${ }^{141}$ Moreover, at Francis I's entry into Nîmes in 1533 the city offered the king a silver replica of its Roman arena. ${ }^{142}$ As we see, towns in possession of Roman remains could use them to their advantage by offering highly distinctive gifts, which drew upon local characteristics. They responded to broader changes in royal fashions in the sixteenth century to devise gifts that endeared the town to the king and persuaded him to make generous grants in return.

Although urban governments hoped that a distinctive gift would encourage the king or his family to keep the item in their personal collections and thus act as an enduring reminder of municipal generoisity, ultimately they had no control over what happened to the piece after it was offered. Catherine de Medici bestowed the solid gold statue she received at her entry into Lyon to Luigi Almanni, who had composed a play for the queen during her stay in the city. ${ }^{143}$ Similarily, when her son, Charles IX, entered Troyes in 1564, he received a statue depicting the three virtues of Justice, Prudence and Force, which was of such intricicay and quality that it took a team of sculptors, goldsmiths and painters six months to complete it. Yet the statue was given away almost

140 Babeau, Rois de France à Troyes, 33-35. See also: Elie Konigson, 'La cité et le prince: premières entrées de Charles VIII (1484-1486)', in Konigson and Jacquot, Fêtes de la Renaissance, iii. 65-66.

141 Rigaud, 'Arles de 1481 à 1588', 479.

142 Achille Bardon, Ce que couta l'entrée de Francois Ier a Nimes (1533) (Nimes, 1894), 3; J. E. Brink, 'Royal Power through Provincial Eyes: Languedoc, 1515-1560', Proceedings of the Annual Meeting of the Western Society for French History 10 (1982), 55; Philippe Chareyre, 'La harangue et le canon: les entrées à Nîmes, au temps des guerres de Religion', in Desplat and Mirronneau, Entrées: gloire et declin, 113 .

143 Cooper, Entry of Henry II into Lyon, 92. During France's frequent foreign wars, the monarch often melted down silverware in royal collections to pay for armies: Kathleen WilsonChevalier, 'Claude de France: In her Mother's Likeness, a Queen with Symbolic Clout?', in Cynthia J. Brown, ed., The Cultural and Political Legacy of Anne de Bretagne: Negotiating Convention in Books and Documents (Woodbridge, 2010), 129. 
immediately to the lord of Carnay, a maitre-d'hôtel. ${ }^{144}$ Despite such losses, many of the gifts offered to the king - particularly those that appealed to a monarch's tastes - were exhibited in royal collections. After receiving a gilded vase from Sens in 1564 , Charles IX thanked the mayor and echevins for the item which he displayed in his private cabinet 'as a rare and precious object'. ${ }^{145}$ Likewise, the statutes of Turnus and Livinia that Tours offered Henry II and Catherine de Medici impressed the king and queen 'not for the value, but for the exquisite structure and manufacture' of the gift, so much so that they decided to keep the items in their cabinets in 'perpetual memory of their entry into the said place of Tours and [of the] excellence of the work.'. 146 This examples testifies to the fact that municipal gifts could function as memory objects and remind the king that these towns had given him an especially impressive entry. From the perspective of urban elites, the most desirable place for the king to display their gifts was in the private rooms where he worked. For this reason, the rulers of Rouen and Sens could hope that the monarch would look at their gifts in the future and keep them in mind as he worked through the business of the state.

Urban gifts were also put on public display at court during royal festivities. ${ }^{147}$ Following the coronation entries of kings and queens into Paris, it was customary to display the very best silverware held in royal collections on the table $d u$ marbre in the great hall of the royal palace during the post-entry banquet. ${ }^{148}$ For Anne of Brittany's coronation entry in 1504, this display was composed of the 'great plates, large basins, heavy cups, large goblets, rich dishes and other pieces of work'. As the gifts were designed to be highly visible, they were surrounded by blazing torches 'as bright as the midday sun'.149 Because the post-coronation banquet was attended by the most powerful people

144 Babeau, Rois de France à Troyes, 61. Municipal councils could attempt to buy back these gifts from the recipients. When Charles Ix handed over to his chaplain the silver cup he had received at his entry into Beaucaire entry in 1564 , the consuls offered to repurchase it for the sum of 40 écus, well aware of the fact that it was actually worth 48 écus: Lamothe, Ville de Beaucaire. Inventaire sommaire des archives communales antérieures à 1790 Série в в (Beaucaire, 1867), 23.

145 Vaillancourt, Entrées solennelles, Charles $I X, 79$

146 Cited in: Rivaud, 'Entrées à Tours', 173-74.

147 For the display of gifts in the collections of French monarchs see: Philippe Henwood, 'Administration et vie des collections d'orfèverie royales sous le règne de Charles VI (13801422)', Bibliothèque de l'Ecole de Chartes 138 (1980), 179-215; Dauphant, Royaume, 275.

148 See also for Louis XI's entry in 1461: Couderc, 'Entrée de Louis XI à Paris', 140.

149 H. Stein, 'Le sacre de Anne de Bretagne et son entrée à Paris en 1504', Mémoires de la Société de l'histoire de Paris et de l'Île-de-France 29 (1902), 299. 
in the kingdom, it was a mark of esteem for urban governments to have their gifts displayed here. In the same way that municipal councils deliberately designed entries to assist the Valois monarchy in the presentation of its power as a means to obtain lucrative grants in return, the display of gifts during royal festivities allowed urban governments to continue to contribute to the display of royal magnificence after the conclusion of the entry. This worked to the benefit of townspeople as their gifts remained visible and reminded the recipient of their obligations to them. In sum, the gift presentation was the most important moment in the ceremony for urban governments to obtain new rights. In order to spell out exactly what they wanted from the king in return for these offerings, civic leaders made a number of requests relating to specific economic, political, military and religious matters.

\section{A Typology of Requests}

As Olivier Mattéoni has observed, requests lay 'at the heart of the dialogue which the prince had to have with his subjects.' ${ }^{50}$ The petitions brought to the king following a royal entry embodied clearly defined goals which civic elites made in the name of the 'common good' as a way to legitimise their authority to speak on behalf of the wider urban population. ${ }^{151}$ Municipal councils used the second harangue (which accompanied the gift giving) to outline the problems they faced. When Chalôns-en-Champagne's échevins offered their gifts to Francis I in 1533, they spoke to him of the city's poverty, the wars that had ravaged the region, the high price of victuals, the outbreaks of plague, and their obligation to care for large numbers of the poor. ${ }^{152}$ Municipal councils used these speeches to justify the need for their petitions because it was essential that requests for new grants were tied to specific problems. Municipal councils devised a range of requests (which they discussed in advance of the entry) in

150 Olivier Mattéoni. "Plaise au Roi": Les requêtes des officiers en France à la fin du Moyen Age', in Hélène Millet, ed., Suppliques et requêtes. Le gouvernement par la grâce en Occident (Rome, 2003), 283.

$15^{1}$ Gisela Naegle, Stadt, Recht und Krone: Französische Städte, Königtum und Parlament in späten Mittelater, 2 vols (Husum, 2002), ii. 76o. See also: Gisela Naegle, 'Armes à double tranchant? Bien Commun et chose publique dans les villes françaises au Moyen Age', in Élodie Lecuppre-Desjardin and Anne-Laure Van Bruaene, eds., De Bono Communi: The Discourse and Practice of the Common Good in the European City (13th-16th c.) (Turnhout, 2010), 55-70.

152 A. Chassaing, ed., Chroniques de Estienne de Médicis, bourgeois de Puy, 2 vols (Le Puy, 1869), ii. 363-64 (also cited in Paradis and Roy, 'Le don', 123). 
the expectation of having one or more granted. ${ }^{153}$ When Charles viII entered Senlis in $\mathbf{1 4 8 4}$, the town council submitted a number of petitions, including: the removal of the impositions placed on the town's drapers; the right to levy a tax on the sale of wine; the opportunity to hold fairs in September, 'and other things.' ${ }^{154}$ Typically, matters relating to urban financial and economic matters formed the bulk of the requests.

\section{Financial and Economic Requests}

The most substantial petitions were those seeking remission of taxes, especially exemption from the taille. This property tax was onerous for urban populations, particularly from the mid-fifteenth century when the Crown levied heavier and more regular taxes in order to pay for its overhaul of the military establishment. ${ }^{155}$ Tailles were levied by province and varied across the kingdom, with some urban communities being taxed more heavily than others. As the taille was collected by region, a town's exemption increased the burden on its neighbours and thus encouraged them to also seek tax exemption. When Charles viII entered Abbeville on 19 June 1493 the mayor successfully petitioned him for exemption from the taille like those of Amiens and other neighbouring towns', while town after town petitioned Francis I's for exemption from the taille during his tour of Normandy in $153^{2} .156$

Towns located on or close to a military frontier had a greater chance of gaining exemption from the taille than those situated in more secure parts of the kingdom. This is because frontier towns were able to persuade the king that

153 For meetings to devise requests, see: Canel, Histoire de Pont-Audemer, ii. 32; Pierre Varin, ed., Archives administratives de la ville de Reims. Collection de pièces inédites pouvant servir à l'histoire des institutions dans l'intérieur de la cité, 3 vols (Paris, 1839-48), ii. 566.

154 BNF Collection de Picardie 5, fol. 121r. When Charles vili entered Compiègne in 1486, the municipal council devised secondary petitions that were to be offered if its primary request (ten years of aides) was refused: Ам Compiègne в в 10, fol. $34 \mathrm{v}$.

155 Jean-François Lassalmonie, La boîte à l'enchanteur: politique financière de Louis XI (Paris, 2002), 48-49; A. Mazure, 'Publication de pièces inédites, relatives au règne de Charles VII', Revue Anglo-Française 3 (1835), 123-24; Jean Nicolas, Julio Valdeón, and Sergij Vilfan, 'The Monarchic State and Resistance in Spain, France, and the Old Provinces of the Habsburgs, 1400-1800', in Peter Blickle, ed., Resistance, Representation, and Community (Oxford, 1997), 68.

156 Ledieu, 'Charles VIII à Abbeville', 59; Lyse Roy, 'Espace urbain et système de représentations. Les entrées du Dauphin et de François Ier à Caen en 1532', Memini. Travaux et documents 5 (2001), 74. When Charles viII entered Reims in 1484 the town council petitioned him for exemption from the taille 'as at the town of Paris': Bartholomé, 'Mémoires de Jean Foulquart', 147 . 
their precarious situation created additional economic and military burdens. When Louis XI entered Honfleur in December 1465, the municipal council successfully petitioned him for taille exemption by stating that the town was obliged to take additional security precautions because it was 'beside our enemies the English. ${ }^{157}$ Although Lancastrian Normandy had collapsed fifteen years earlier, Honfleur's échevins claimed that a persistent threat of English attack meant that they had to keep their fortifications in good order and take additional security precautions. Towns that could demonstrate a national strategic importance received substantial tax remissions. Urban governments on the eastern frontier such as Abbeville argued that they deserved major economic grants because they were at the forefront of France's wars in the sixteenth century. When Henry II entered Chalôns-en-Champagne in 1552, he granted the inhabitants perpetual exemption from the taille because of the loyalty and obedience of the inhabitants.'158 This grant was of such magnitude that the Cour des Aides refused to register it, claiming the tax remission was unduly detrimental to royal finances. As a consequence, Henry II wrote to his officials in the Cour des Aides on 2 September to compel them to register his grant. Henry's actions can be explained by the geopolitical situation of Châlons, which lay at the centre of the conflicts between France and the Holy Roman Empire. When Emperor Charles v invaded Champagne in 1544 and captured the nearby town of Saint-Dizier, it was in Henry's interests to ensure that Chalôns remained strong, especially as he launched a campaign from Champagne into imperial lands in 1552. Indeed, Chalôns proved its value to the Crown later that year by sending its masons and carpenters to help defend Metz against Charles v's armies. ${ }^{159}$ While relief from the taille tended to be restricted to strategically important towns and cities, kings could also grant exemptions in extraordinary circumstances. Louis XI entered Toulouse in 1463 nineteen days after a devastating fire had destroyed three quarters of the city. The conflagration sparked off a major economic crisis in Toulouse and Louis attempted to assist the city by awarding it exemption from the taille for ten years. ${ }^{160}$ As the granting of a general tax exemption was particularly detrimental to royal finances, urban governments had to demonstrate that remission from the taille was ultimately to the Crown's benefit. It was in Louis's interests to help rebuild Toulouse's

157 P.-P. U. Thomas, Histoire de la ville de Honfleur (Honfleur, 1840), 425-27.

${ }_{158}$ Municipal deliberations cited in: Barthélemy, Histoire de Chalons-sur-Marne, 201.

159 Knecht, Renaissance France, 216-18.

16o AM Toulouse AA 3/375. He also pardoned the husband and wife bakers who had started the fire: Bonnafous, 'Toulouse et Louis XI', 17. 
economy because the city paid one quarter of Languedoc's taille in the midfifteenth century. ${ }^{161}$

In addition to winning exemptions from national taxation, urban government also brought requests to the king relating to local economic issues, such as the permission to hold fairs or establish markets. For example, when Charles IX entered Mâcon in 1564, the town council petitioned him for the right to establish a market for the butchers. ${ }^{162}$ This type of petition was commonly granted at entries, probably because it did not have a detrimental effect on royal finances (unlike exemption from the taille). Fairs and markets were the lifeblood of urban communities and municipal governments competed against each other for the right to hold them. ${ }^{163}$ When Louis XI made his inaugural entry into Lyon in 1462, the king awarded the city the right to hold four fairs; when he retuned to the city in 1474, the échevins petitioned the king for the maintenance of these fairs. ${ }^{164}$ While Fernand Braudel has described Louis's initial granting of fairs to Lyon in 1462 as the city 'entering upon its modern destiny', in fact by the time of Louis's second entry Lyon was struggling to preserve its fairs against encroachments from towns in Burgundy and Champagne. ${ }^{165}$ The significance of Lyon's fairs transcended their economic value because they were an important guarantee of its security. In comparison to many cities on the eastern frontier, Lyon's fortifications were not particularly strong. This is because the city's location on the commercial crossroads between France, Italy, the Holy Roman Empire, and the Swiss cantons meant that it was not in the interests of any of these powers to see the city destroyed. It is striking to note that in contrast to the experiences of other cities on the eastern frontier, Lyon was not besieged during the Valois-Hapsburg conflicts of the sixteenth century. As Lyon's commercial importance was crucial to its security, its rulers

\footnotetext{
161 Bonnafous, 'Toulouse et Louis XI', 14.

162 Aм Mâcon вв 39, fols 95 r-95v.

163 Naegle, 'Vérités contradictoires', 730-32, 742-43.

164 Guenée and Lehoux, Entrées royales françaises, 219; Champdor, Rois de France à Lyon, 18-19. Indeed, the city council requested confirmation of the right to hold these fairs through to the mid-sixteenth century: Ам Lyon в в 66, fol. 26r. For encroachments on Lyon's fairs see: Naegle, Stadt, Recht und Krone, i. 90; Rivaud, Villes et le roi, 199; Ordonnances et privileges des foires de Lyon: et leur antiquité: avec celles de Brie, \& Champagne, et les confirmations d'icelles, par sept roys de France, depuys Philippe de Valois, sixieme du nom: iusques à François second, à present regnant (Lyon, 156o); M. Bressard, Les foires de Lyon aux XVe et XVIe siècles (Paris, 1914), 22-104; A. Bernier, ed., Procès-verbaux des séances du conseil de régence du roi Charles VIII pendant les mois d'août à janvier 1485 (Paris, 1836), 155.

165 Fernand Braudel, The Identity of France, trans. Siân Reynolds 2 vols (London, 1988), i. 211.
} 
were concerned that losing the fairs would compromise their situation. ${ }^{166}$ The city's neutrality lay at the heart of its development into an international trading city during the second half of the fifteenth century. Not only were large numbers of foreign merchants based in the city, the Medici bank transferred its regional branch from Geneva to Lyon in 1465 because of the commercial security the city offered. ${ }^{167}$ The consuls were able to use a royal entry to obtain the safe keeping of their fairs and thus bolster Lyon's increasingly dominant economic position in the kingdom.

Urban communities used royal entries to try and take privileges from their neighbours. When Charles viII entered Mâcon in June 1494, the échevins petitioned the king to return the mint to their town (Charles VI had transferred the mint from Mâcon to Lyon in 1389 in return for the magnificent entry he had received there). ${ }^{168}$ Towns also competed on a national level to obtain the same rights as other urban centres. When Francis I made his inaugural entry into Bourg-en-Bresse in 1544, the consuls asked him for permission to establish a silk industry in the town as well as the privilege to trade this silk throughout the kingdom without having to pay custom duties, like 'those of Tours and elsewhere.' ${ }^{169}$ The French silk trade was in turmoil in the early 1540 s because of the commercial damage brought about by the Italian wars. Indeed, the artisans of Tours (which was a major centre of silk production) rioted in 1542 as a consequence of the damage foreign conflicts were causing to city's industry. The 1540 s was also a period of increasingly bellicose economic competition in the French silk trade, with many towns (such a Bourg-en-Bresse) attempting to move into the fabrication of this luxury good. The economic revival of the late fifteenth century was beginning subside and in real terms the purchasing power of the bulk of the French population was suffering noticeably in the 1530 and 1540 s. Yet silk was produced for the pre-eminent members of French society, who felt the effects of the economic downturn less severely and who could still afford exclusive luxury goods. ${ }^{170}$ By moving into silk production, towns which were suffering from this economic downturn hoped to tap into one of the most lucrative industries in sixteenth-century France. As such,

166 Likewise, Tournai's rulers feared that the overhaul of its fortifications would threaten the neutrality upon which the city's security depended: Rolland, Histoire de Tournai, 179; Neil Murphy, 'Tournai under Tudor Rule: Cooperation or Opposition?', Mémoires de la Société royale d'histoire et d'archéologie de Tournai 12 (2014), 34.

167 Ladurie, Royal French State, 44-45.

168 Bazin 'Rois de France à Mâcon', 62; Champdor, Rois de France à Lyon, 13-14.

169 E. Millet, Entrée de François Ier à Bourg-en-Bresse le 1er octobre 1541 (Paris, 1877), 6.

170 Potter, Nation State, 289. 
Bourg-en-Bresse - which had only recently become French - used Francis I's inaugural entry to expand the scope of its economic activity by claiming that their status as subjects of the French king entitled them to the same rights as those towns which lay at the centre of royal power, such as Tours.

Civic councils had a greater chance of winning grants if they explained how they would use these grants to curb specific problems. In order to help Rouen pay for its contribution to the war subsidy (soulde), following his entry in $155^{\circ}$ Henry II approved the échevins' request to levy a tax of 5 sous on a range of goods sold in the city. ${ }^{171}$ The granting of this request benefitted the king as it allowed Rouen's government to raise the money he needed to fight in Italy. It was generally in the monarch's interest to help municipal administrations overcome their economic difficulties because it would ultimately generate more tax revenue for the Crown. At Charles viri's entry into Poitiers on 15 February 1487 , the town council presented the king and his council with a petition seeking 1,000 livres per year from the Crown 'to help to support the costs and expenses of the said town.' ${ }^{172}$ The consuls explained that they were making this request because of the recent decline of the town's cloth industry, upon which much of their wealth was based. The root of Poitiers' problems lay in Louis XI's expulsion of Arras's population a decade earlier. After renaming the city Franchise, Louis offered economic incentives to persuade merchants and artisans from across France to relocate to the city. ${ }^{173}$ This policy was detrimental to Poitiers' industry, as many of the town's cloth workers moved to Franchise. ${ }^{174}$ Whereas the ramifications of Louis's efforts to repopulate Arras/ Franchise had led to violence from workers at Limoges in 1480, Poitiers' municipal council sought to avoid such disorder (which threatened the town's internal stability and weakened their position with the king) by using a royal entry

171 C. M. de Robillard de Beaurepaire, Ville de Rouen. Inventaire sommaire des archives communales antérieures à 1790 (Rouen, 1887), 171.

172 Rivaud, Entrées princières, 124.

173 Robert Favreau, La ville de Poitiers à la fin du Moyen Age: Une capitale régionale, 2 vols (Poitiers, 1978), ii. 435-36. For Louis XI's failed attempt to repopulate Arras, see: A. Laroche, 'Une vengeance de Louis XI', Mémoires de l'Académie des sciences, lettres et arts d'Arras 37 (1865), 237-356; M. Caillet, Repeuplement de la ville d'Arras sous Louis XI: rôle de Lyon (1908); Henri Stein, 'Les habitants d'Évreux et le repeuplement d'Arras en 1479', Bibliothèque de l'École des Chartes 84 (1923), 284-97; idem, 'La participation du pays de Languedoc au repeuplement d'Arras sous Louis XI', Bibliothèque de l'École des Chartes 92 (1931), 62-69.

174 P. M. Raveau, 'Les rapports entre Louis XI et le Conseil de Ville de Poitiers', Bulletin de la Société des antiquaires de l'Ouest 8 (1928), 97-98. 
to win concessions from the Crown to ameliorate the situation. ${ }^{175}$ The rulers of Poitiers wanted Charles viII to grant them financial exemptions on tools and taxes in the hope that this would persuade cloth workers to come and settle in the town. ${ }^{176}$ While Poitiers' consuls had spent a decade at court trying to obtain these grants from the king, their efforts had ended in failure. The petitions were successful in 1487 precisely because a royal entry provided them with direct access to the king and bound him to grant the city's requests.

\section{Defence}

Issues relating to urban defence formed the second principal type of request that urban administrations made to the king and his representatives during an entry. These requests were tied up with fiscal matters because urban elites justified their petitions regarding taxation by claiming they would put the money towards the construction and maintenance of fortifications. Towns developed into significant military centres during the Hundred Years' War, which allowed them to win major economic concessions at entries because the Crown was more inclined to issue economic grants when the profits went towards ensuring the kingdom's security. Towns frequently asked the king for the right to keep the profits of a specific tax (octroi), which usually came in the form of a sales tax. When Francis I entered Beauvais in 1520, the échevins asked him for permission to collect the revenue from a tax on sale of fish, stating that the profits would be used to pay for the upkeep of its defences. ${ }^{177}$ Octrois were granted for a set number of years (normally between two and ten), though they could be renewed at royal entries. With the end of the Hundred Years' War, the granting of octrois (as with exemption from the taille) became more common in the frontier regions of the kingdom such as Burgundy, Champagne and Picardy, which were regularly menaced by foreign troops. ${ }^{178}$ The allocation of octrois at entries was vital to the security of those urban communities that were unfortunate enough to be at the centre of the Valois-Habsburg conflicts.

175 For Limoges, see: René Gandilhon, Politique économique de Louis XI (Paris, 1941), 121-35.

176 For Charles VIII's granting of this request at his entry see: Rivaud, Entrées princières, $123-24$.

177 Bм Beauvais, Coll. Bucquet, vol. 57, p. 422.

178 Naegle, Stadt, Recht und Krone, ii. 744. For other examples of grants made at a royal entries to pay for the construction and maintenance of urban fortifications in frontier towns, see: AM Compiègne вв10, fol. 34v; Ledieu, 'Charles VIII à Abbeville', 57; B. H. J. Weerenbeck, ed., Comptes de la ville de Doullens pour l'année 1470 et cueilloir de cens dus au béguinage de cette ville (Paris, 1932), 13; M. E. Delogove, Histoire de la ville de Doullens (Amiens, 1865), $242-43$. For the overhaul of the fortifications of Champagne and Burgundy after 1500 see: Dauphant, Royaume, 242. 
Financial concessions and economic grants allowed these towns to keep up to date with the latest developments in military technology, especially during the first half of the sixteenth century when Italian engineers oversaw the modernisation of urban fortifications along France's eastern frontier. ${ }^{179}$ For example, the fortification grants issued at royal entries into Dijon in the late fifteenth and early sixteenth century ensured that the city's defences were in a good state when it was besieged by an imperial army in $1523 .{ }^{180}$ Furthermore, the extensive grants accorded by Francis I following his entries into Langres (1521) and Péronne (1539) allowed these towns to demolish their redundant medieval walls and construct state-of-the-art modern fortifications in their place. ${ }^{181}$ It was advantageous for towns to receive a royal visit, as the king could see their dangerous situation first hand and thus be more inclined to make defensive grants. In 1494 Charles VIII made entries into the Burgundian towns that lay on the Saône, including Dijon, Nuits, Châlons, Beaune, Auxonne and Saulxle-Duc. This river marked the boundary between France and the Holy Roman Empire and Charles was able to see imperial horses being brought to drink in the Saône on the opposite bank of the river (which highlighted the immediacy of the threat of invasion), as well as the state of urban fortifications along this important frontier. ${ }^{182} \mathrm{~A}$ royal visit highlighted both the precarious situation of these towns and the crucial role they played in the defence of the kingdom, and made it likely that they would receive substantial economic liberties from the Crown at an entry. Charles viII granted octrois to all the places he visited on his tour of the Burgundian frontier towns in 1494 specifically so that they could repair their fortifications during this time of heightened tension with the Empire. In addition to the military value of urban fortifications, city walls were a crucial symbol of urban power and identity; indeed, possession of walls was often used to define whether or not a settlement could be considered a town. ${ }^{183}$ Thus, by making grants towards the construction and maintenance

179 Fawtier, Ville classique, 121; David Potter, Renaissance France at War: Armies, Culture and Society, c.1480-156o (Woodbridge, 2008), 157-86.

18o For the fortification grants made by Charles VIII following his entry into Dijon in 1494 see: M. Rossignol, 'Histoire de Bourgogne: Charles VIII', Mémoires de l'Académie des sciences, arts et belles-lettres de Dijon 9 (1861), 136. For the siege of Dijon see: Laurent Vissière, 'Sans poinct sortir hors de l'orniere': Louis II de La Trémouille (1460-1525) (Paris, 2008), 224-30; Catherine Chédeau, 'Le siège de Dijon in 1513', in G. Audisio, ed., Prendre une ville au XVIe siècle (Aix-en-Provence, 2004), 17-32.

181 Jules Dournel, Histoire générale de Péronne (Péronne, 1879), 192; Boullaye, Inventaire sommaire, Langres, 106, 118.

182 Rossignol, 'Charles VIII', 136.

183 Braudel, Identity of France, 179. 
of city walls the French Crown also helped to maintain a keystone of urban identity and independence.

As well as protecting the kingdom against foreign invasion, requests relating to urban security reflected France's internal military and political conditions. During the Hundred Years' War, French towns used entries to petition the king to act against the bands of mercenaries (routiers) terrorising urban communities. Indeed, Charles vir's mercenary captains were as prone to intimidate the Valois monarch's own supporters as they were to attack the population of Lancastrian France. When Charles VII entered Limoges in 1439, the municipal council informed him about the depredations caused by a local mercenary company. ${ }^{184}$ Like other regional centres, Limoges' commercial prosperity derived from its ability to participate in local trade, which was dependent on peace and stability. The character of the warfare prosecuted by the mercenary companies (which included pillaging, extortion and the harassment of merchants) was devastating for urban populations. In return for ending the mercenaries' subjection of the region, the population of the Limousin gifted Charles the large sum of 20,000 livres, while Limoges contributed a further 3,00o livres (this was in addition to the 4,500 livres the consuls had already spent on presents for his entry). The scale of the gifts Charles received during his visit to Limoges reflected the degree of royal assistance sought by the region's population, who expected the cash to be used to pay for soldiers to end mercenary activity in the region. ${ }^{185}$ Problems with mercenaries persisted in some regions of the kingdom throughout the sixteenth century, particularly in the south where their infractions (including rape, arson and assault) were the source of constant complaints from the Estates of the Languedoc to Francis I ${ }^{186}$ Royal entries offered municipal councils an opportunity to speak directly to the king and obtain an immediate end to the disorder his soldiers caused. Following Francis I's entry into Béziers in 1542, the region's inhabitants came to the monarch to complain that mercenaries in his pay had kidnapped three hundred local women. As a result, Francis had the women ransomed and returned to

184 A. Leroux, 'Passages de Charles VII et du dauphin Louis à Limoges en 1439, des mêmes et de la reine de France en 1442', Bibliothèque de l'École des Chartes 46 (1885), 309; Tricard, 'Entrées royales à Limoges', 408.

185 C. Chabanneau, 'Cartulaire du consulat de Limoges', Revue des études Romanes, 4 series 8 (1895), 223 .

186 J. E. Brink, 'Louise de Savoie, "King” of France 1525-1526', Proceedings of the Annual Meeting of the Western Society for French History 9 (1981), 22. For the problems with maintaining discipline in French armies, see: Potter, Renaissance France at War, 248-54. 
their families. ${ }^{187}$ There are a number of reasons why it was important that municipal governments had the opportunity to bring requests to the king regarding his soldiers' depredations. First, more urban revolts in early sixteenthcentury France were provoked by the actions of 'friendly' troops than by tax reasons. ${ }^{188}$ As urban governments were responsible for maintaining order for the king, any outbreak of disorder amongst the general population could result in punishment. Second, urban governments stretched their budgets in order to pay armed forces to protect them from French soldiers. ${ }^{189}$ Third, having royal intervention in this matter was important for civic governments because soldiers often operated outside the normal parameters of the provision of justice in the localities, which meant that it was not easy to use local courts to punish them. ${ }^{190}$ By listening to urban requests and putting a stop to the depredations his soldiers caused, the king could demonstrate that he was listening to his subjects' principal grievances and responding to them accordingly.

Yet while urban governments wanted the Crown to bring its soldiers to heel and cover the costs of maintaining municipal fortifications, they also wanted to retain their military autonomy. ${ }^{191}$ As civic leaders lacked the necessary expertise to defend their populations from attacks by professional soldiers, captains played a crucial role in the organisation of urban military resources. In those towns where the Crown named the captain, there was a risk that this position would be granted as an honour to one of the ruler's favourites, who would then reside elsewhere. As such, municipal governments faced the problem of absenteeism. This was a serious issue for urban populations, especially during periods of intense warfare when it put their security (and commercial activities) in jeopardy. For example, the captain of Amiens, Jean de Beeloy, was almost entirely absent from the city during the 1420 s and 1430s, which meant that it was unprepared to face the mercenary soldiers that poured into the region with the resurgence of Charles VII's power after $1429.192 \mathrm{In}$ order to avoid such situations, urban governments petitioned the king for the right to name their own captain at royal entries. They wanted to be able to

\footnotetext{
187 Histoire générale de Languedoc, xi. 267-68. For complaints about mercenaries, see: Potter, Nation State, 34 .

188 Potter, Nation State, 159; Henry Heller, Iron and Blood: Civil Wars in Sixteenth-Century France (Montreal, 1991), 44-45.

189 Heller, Iron and Blood, 24-25.

190 Bernard Chevalier, 'La réforme de la justice: utopie et réalité (1440-1540)', in André Stegman, ed., Pouvoir et institutions en Europe au XVİ̀me siècle (Paris, 1987), 243.

191 Chevalier, Bonnes villes, 113-28.

192 Neil Murphy, 'Between France, England and Burgundy: Amiens under the Lancastrian Dual Monarchy, 1422-1435', French History 26 (2012), 158-59.
} 
appoint a trusted and capable local military expert who would reside in the town, oversee matters of defence, and protect both its merchants and those who came to trade at its markets. When Charles vi entered Péronne in 1382, he granted the town the right to elect its own captain. As Péronne stood on the frontier with Flanders (from where Charles vi was returning after a successful military campaign against the Flemish towns), the town's defence was a key issue for both the Crown and the municipal government. Hence, it was in the interests of the monarch to have the position filled with a captain who was based in Péronne. Grants relating to urban security could be long standing and Péronne held on to the right to name its captain right through to 1560 , when the responsibilities of the position were transferred to the governor of Picardy. ${ }^{193}$ Overall, civic governments used royal entries to ask the king to intercede in a number of ways relating to urban defence while at the same time seeking to keep their autonomy undiminished.

\section{Urban Justice and Administration}

Although matters relating to urban economic and military concerns formed the bulk of the requests municipal councils submitted to the king at an entry, some petitions related to matters of justice and administration. Like the king's guarantees of municipal political and economic rights, those relating to justice sought to preserve local or regional jurisdictions. Following Henry II's entry into Rouen in 1550, the town council claimed that their privileges entitled the city's inhabitants to appear only before the judges of the region's ressort (a designated juridical area) rather than being tried by other authorities. ${ }^{194}$ An entry also offered towns the opportunity to bring concerns regarding the implementation of justice by other regional judicial institutions such as the bailliage, the sénéschausée and the parlement. When Philip VI entered Narbonne in 1336, the town presented the king with a remonstrance containing forty-one articles concerning the reform of justice in the region. Narbonne's leaders asked the king to strip the notaries of the sénéschausée of their right to receive gifts because they were extorting money from the townspeople. ${ }^{195}$ Ceremonial entries also provided civic councillors with an opportunity to inform the monarch and his agents about infractions on municipal jurisdiction. Following his entry into La Rochelle in 1491, the town council asked Charles, count of Angoulême, to persuade Charles viII to restore the former authority of the town council, 'which jurisdiction the provost of the said town and other royal

\footnotetext{
193 Dournel, Histoire de Péronne, 116.

194 Beaurepaire, Inventaire sommaire, Rouen, 172.

195 AM Narbonne AA 162.
} 
officers were trying to destroy and suppress' by having their case heard in the conseil privé. ${ }^{196}$ As La Rochelle's consuls did not have privileged access to the conseil privé (in contrast to the city's royal officers), they used their access to the duke to persuade him to ask the king to restore their authority.

The duty to remove corruption from the judicial system lay at the heart of late medieval and early modern conceptions of French kingship; namely, that as the successor of Louis IX, the French king was obliged make progresses around his kingdom so that he could hear his subjects' judicial complaints. Moreover, when the French Crown set about reforming of the provision of justice in the mid-sixteenth century, municipal governments were able to obtain grants at royal entries which expidited townspeople's access to justice. When Henry II entered Évreux in 1550, he received complaints from the town council about the length of procedures in the Parlement in Paris which he resolved by installing a siège présidial (a local tribunal court) at Évreux. ${ }^{197}$ Requests relating to judicial matters also placed towns in competition with their neighbours. When Francis I visited Le Puy in 1533, the civic council petitioned him to establish a siège présidial in the town, which was to the detriment of the sénéchaussée of Nîmes. ${ }^{198}$ As well as speeding up justice and maintaining local jurisdiction, the installation of a seat of justice also allowed towns to prosper economically because (like the possession of a cathedral or site of religious significance) it drew people and their money into the town from the surrounding region. ${ }^{199}$

Although urban elites claimed that economic and military petitions benefitted the entire community, many requests were unmistakably aimed at consolidating their wealth and social position at the expense of other social groups. When Charles viII entered Rouen in 1485, he granted the townspeople exemption from the franc-fief, which was a tax due on land owned by non-nobles. ${ }^{200}$ Rather than profiting the entire population, this grant was only of benefit to the city's wealthy merchants, who were attempting to move into landholding in a bid to gain noble privileges. ${ }^{201}$ This grant was particularly important in the north of kingdom where the taille was based on an individual's social

\footnotetext{
196 Rivaud, Entrées solennelles, 128.

197 T. Bonnin, 'Notes sur les entrées solennelles des rois de France à Évreux', Recueil de la Société libre d'agriculture, sciences, arts et belles-lettres du département de l'Eure 9 (1838), 119-20.

198 Paradis and Roy, 'Le don', 138.

199 Braudel, Identity of France, i. 183-84; Small, Late Medieval France, 180-81.

200 Beaurepaire, 'Charles VIII à Rouen', 294-95.

201 Georges Huppert, Les bourgeois gentilshommes: an essay on the definition of elites in Renaissance France (Chicago and London, 1977).
} 
status (known as the taille personnelle). Hence, noble status conferred exemption from the taille. This was in contrast to the situation in the south of the kingdom, where the taille was assessed on the status of the land (taille réele), which meant that many nobles had to pay land taxes. Overall, the bulk of the taille fell on the population of north of the kingdom, especially wealthy nonnobles such as Rouen's merchants. ${ }^{202}$ The wider socio-political context of the entry made it especially amenable for Rouen's ruling elite to present the king with a petition that was specifically designed to promote their interests. Louis, duke of Orléans, who was then leading the noble rebellion known as the Guerre Folle, claimed that the regent of the kingdom, Anne of Beaujeu, was abrogating local rights and autonomy in an attempt construct a despotic form of government. ${ }^{203}$ Louis attempted to build a support base amongst the elite of northern towns by posturing as the champion of urban liberties. By having Charles VIII grant Rouen's elite exemption from a land tax, the Beaujeu administration attempted to regain the support of the rulers of one of the kingdom's principal cities. ${ }^{204}$ Louis XI had used the same tactic to win the city's support in the mid-146os, when he re-established royal power in Normandy by undermining regional support for the princes who had rebelled against the Crown in 1465 . When Louis entered Rouen in June 1467 , he granted the town council exemption from the obligation to pay a tax on the acquisition of noble properties 'considering the great and good loyalty that our dear and well-loved bourgeois and inhabitants of the good town and city of Rouen have always had towards our predecessors.' ${ }^{205}$ Despite Louis's warm words, the city had in fact supported the rebel princes during the War of the Public Weal; nonetheless, the grants the king made at his entry into Rouen derived from considerations of practical politics. While Louis had re-imposed his rule over Normandy, his authority in the region was still weak. As such, he granted lucrative concessions to Rouen's ruling elite as a means to bind their interests to those of the Crown and secure their future support.

Civic elites asked the king to grant them the means to impose their rule over general urban populations. Following his entry into Poitiers 1487 , the ruling elite asked Charles VIII 'to support thirty or forty archers in the said town to be subject to the mayor'. ${ }^{206}$ Essentially, the municipal council wanted to establish

\footnotetext{
202 David Parker, The Making of French Absolutism (London, 1983), 19.

203 J. S. C. Bridge, A History of France from the Death of Louis XI, 5 vols (Oxford, 1921-36), i. 122.

204 Knecht, Renaissance France, 24; Bridge, History of France, 126.

205 Laurrière, Ordonnances rois de France, xvi. 579-81; Beaurepaire, 'Six voyages de Louis XI', 306.

206 Rivaud, Entrées solennelles, 124.
} 
a militia in order to strengthen its grip over the town. Civic elites also won grants at royal entries which allowed them to clamp down on assemblies of the lower urban orders. These rights were a mark of considerable municipal power, particularly because assemblies of townspeople were a potential threat to the elite's control of urban political and economic structures. In 1474 Louis XI granted Lyon's municipal council extensive powers over the craft guilds, which were no longer permitted to assemble together and 'make statutes and ordinances touching their guilds without the assistance and presence of the said councillors [i.e. the town council].207 Because the guilds did not have the same access to the king as that enjoyed by the municipal council, they were unable to promote their concerns to the monarch. As a result of such grants, Lyon's municipal council gained control over the city's craft guilds and kept them weak. The consuls gained the right to nominate the guild masters who in turn nominated the councillors and consuls, thus maintaining the elite's dominance of the city's government. Consequently, Lyon's municipal council was at the height of its powers by the mid-sixteenth century. ${ }^{208}$ In short, rather than acting in the interests of all urban groups, municipal governments used royal entries to petition the king for grants that were intended to consolidate their domination of general populations. In return for buttressing their authority, the monarch expected urban elites to use these powers to maintain order and stability on his behalf in the provinces. This symbiotic relationship was particularly important during times of civil conflict, most notably during the Wars of Religion.

\section{Religious Requests}

In addition to requests regarding justice and administration, petitions relating to matters of faith were offered to the king. While requests relating to religious groups were rare before $155^{\circ}$, the nature of the conflicts of the second half of the sixteenth century encouraged this type of petition. With the spread of Protestantism amongst urban populations and the kingdom's

207 Guenée and Lehoux, Entrées royales françaises, 220.

208 For the conflicts between Lyon's consuls and the guilds, see: Richard Gascon, Grand commerce et vie urbaine au XVIe siècle: Lyon et ses marchands (environs de 1520-environs de 1580), 2 vols (Paris, 1971), i. 407-33; Caroline Fargeix, 'La querelle des artisans et des consuls: mémoire, pouvoir et conflit à Lyon au début du XVI e siècle', in Philippe Hamon and Catherine Laurent, eds., Le pouvoir municipal: de la fin du Moyen Âge à 1789 (Rennes, 2012), 253-69; A. Bassard, 'La querelle des consuls et des artisans à Lyon (1515-1521)', Revue d'histoire de Lyon 8 (1909), 1-42; Carloine Fargiex, Les élites lyonnaises du XVe siècle au miroir de leur langage. Pratiques et representations culturelles des conseillers de Lyon, d'après les registres de délibérations consulaires (Paris, 2007), 484-530. 
collapse into civil war during the 1560 s, religious requests were brought before Charles IX and Catherine de Medici during their progress of 1564-66. ${ }^{209}$ When Charles IX entered Angoulême in August 1565, the Protestant leader Jacques de Boucart made a speech before the king and the consil privé in which he lamented the persecution of his co-religionists. The queen and conseil listened agreeably to this address, assuring Boucart that the strengthening of royal authority in the region would benefit its Protestant population. ${ }^{210}$ However, not all religious requests were received favourably. When Charles Ix entered Sens in March 1564 he entered a staunchly Catholic town, whose Protestant population had been slaughtered in the previous year. Robert Hémard, lieutenant criminel of the bailliage, former mayor of the town and one of the leaders of the massacre, delivered the welcoming speech to Charles Ix. Sens' Catholic leaders used their control of the entry to gain access to the king and influence his response to the massacre. When Jacques Penon - a Protestant who had fled the killing - returned to Sens to present Charles IX with a protest regarding the attacks, he was accused of sedition. ${ }^{211}$ Although the Crown had informed Jacques de Boucart it would support Protestant rights, many royal entries in the 1560 s were used to strengthen Catholic domination of local political structures. When Charles IX entered Nîmes in December 1564, the recently elected Catholic consuls (who replaced a Protestant council) petitioned the king for a series of measures designed to reinstall Catholic dominance in the town. ${ }^{212}$ Likewise, Charles IX granted Agen the town the right to hold annual elections for six consuls in $1565 .{ }^{213}$ The reformation of Agen's communal government

209 These religious issues are also reflected in the nature of the pardons Charles issued during this progress: Michel Nassiet, ed., Les lettres de pardon du voyage de Charles IX (1565-1566) (Paris, 2010).

210 J.-F. Eusèbe Castaigne, 'Entrées solennelles dans la ville d'Angoulême depuis François Ier jusqu'à Louis XIV', Bulletin de la Société archéologique et historique de la Charente 1 (1856), 311-12; La harange prononcee par le sieur de Boucart deuant la Maiesté du roy estant en son Conseil priué à Angoulesme le xvie jour d'aoust, mil cinq sens soixante cinq (1565), printed in Louis Condé, Mémoires de Condé: ou recueil pour servir à l'histoire de France, contenant ce qui s'est passé de plus mémorable dans la royaume, sous la règne de François II, \& sous une partie celui de Charles $I X, 6$ vols (London, 1743), v. 367 .

211 Vaillancourt, Entrées solennelles, Charles IX, 61-62.

212 However, a request that that Protestants serving on the cour présidial would be removed from office was not granted because it would have impacted on royal finances: Tulchin, Triumph of Protestantism, 157; Menard, Histoire civile, iv. 404-5.

213 Rivaud, 'Entrées à Tours', 164; Auguste, Inventaire sommaire, Agen, 29; Bernard Labénazie, Histoire de la ville d'Agen et pays d'Agenois suivie des annales ou chronique agenoise, 8 vols (Agen, 1888), i. 259-61. 
was linked to the re-establishment of royal power in southwestern France, which lay at the centre of the kingdom's religious wars. While Agen had a large Protestant population, its Catholic leaders remained staunchly loyal to the Crown, in return for which the monarch buttressed their authority over the town. ${ }^{214}$ Yet not all religious requests related to Christians. When Henry II entered Lyon in 1548 , the town council planned to inform the king that 'the Jews and Moors who were chased from the emperor's lands' had come to live in the city. ${ }^{215}$ The consuls considered the presence of the Jews in the city to be a 'great scandal to the Christian religion. ${ }^{216}$ Yet there was also an economic element to this complaint as the Jews had opened a business in the city centre without first gaining the municipal council's permission. ${ }^{217}$ In other words, the Jewish traders had challenged the municipal council's authority. Regardless of religion, an entry allowed those who were in power to gain access to the king, which they could use to seek rights that were to the detriment of others, whether they be guildsmen, Jews or Protestants.

\section{Conclusion}

While a royal entry began to lose its central role in the ratification of existing municipal liberties from the mid-fifteenth century, it remained one of the very best times for civic elites to win new rights and liberties. It was important that urban requests for new liberties followed the public entry because by the time the king received the town's petitions he had processed through the city streets and witnessed a series of spectacles devised by the urban elite which celebrated the French monarchy. Furthermore, towns offered gifts of silverware to recognise the king's right rule. As with the reciprocal swearing of oaths, the gift presentation was a remnant of the feudal relationship urban governments had entered into with the king during the urban resurgence of the twelfth and thirteenth centuries. In return for this display of idealised kingship, municipal elites expected the monarch to use his power to sustain their elevated position in the urban hierarchy, as well as improving the town's economic situation. While historians have devalued the economic benefits of royal entries for urban communities, there was a clear link between the town's gift and the king's counter-gift. By placing reciprocal obligations on both parties,

\footnotetext{
214 Stéphane Baumont, Histoire d'Agen (Toulouse, 1991), 118-22.

215 Ам Lyon в в 67, fol. 232v.

216 Ам Lyon в в 67, fol. 25or.

217 Ам Lyon в в 69, fol. $3 \mathrm{v}$.
} 
the post-entry gift exchange embodied the broader interdependent relationship that existed between the king and the urban elite. This was, of course, an unequal relationship and in return for shoring up his power the king granted urban elites privileged access to his person, which they could use to petition him for new liberties.

Custom obliged the monarch to award new liberties as part of a royal entry. Towns specifically waited until an entry to bring their requests to the king as it was the best time to have petitions granted. When Lyon's consuls learned on 7 October 1456 that Charles VII planned to visit the city, they decided to wait until the entry to petition him for a reduction of its military burden. ${ }^{218}$ It was essential that towns provided the king with gifts that were appropriate to their place in the urban hierarchy. When urban councils failed to do so, there was no obligation for the king to respond. Nevertheless, in most cases urban governments had some or all of their requests granted by the monarch. However, obtaining the king's sanction was only the first stage in the enactment of petitions. As we will see in the next chapter, municipal councils had to enter into protracted discussions with royal officials to have the grants implemented.

218 Ам Lyon в в 8, fol. 27r; Caillet, Relations de la commune, 149. 